Andrews University

Digital Commons @ Andrews University

1979

\title{
The Contextualization of an Understanding of Biblical Preaching into the Jamaican Situation
}

Vassel George Kerr

Andrews University

Follow this and additional works at: https://digitalcommons.andrews.edu/dmin

Part of the Practical Theology Commons

\section{Recommended Citation}

Kerr, Vassel George, "The Contextualization of an Understanding of Biblical Preaching into the Jamaican Situation" (1979). Professional Dissertations DMin. 573.

https://dx.doi.org/10.32597/dmin/573

https://digitalcommons.andrews.edu/dmin/573

This Project Report is brought to you for free and open access by the Graduate Research at Digital Commons @ Andrews University. It has been accepted for inclusion in Professional Dissertations DMin by an authorized administrator of Digital Commons @ Andrews University. For more information, please contact repository@andrews.edu. 
NOTE

This Doctor of Ministry project report falls in a category described in the Seminary Bulletin as "Project II" in fulfillment of requirements for an alternate curriculum plan under which the candidate prepares two related papers--a theological position paper addressing some issue or problem in the church theologically, and a professional paper addressing this issue or problem from the standpoint of ministerial practice. 


\begin{abstract}
Andrews University
Seventh-day Adventist Theological Seminary
\end{abstract}

THE CONTEXTUALIZATION OF AN UNDERSTANDING OF BIBLICAL PREACHING INTO THE JAMAICAN SITUATION

\author{
A Project Report \\ Presented in Partial Fulfillment \\ of the Requirements for the Degree \\ Doctor of Ministry
}

by

Vassel George Kerr

August 1979 

THE CONTEXTUALIZATION OF AN UNDERSTANDING OF

BIBLICAL PREACHINî̃ INTO THE

JAMIACAN SITUATION

A project presented

in partial fulfillment of the requirements

for the degree

Doctor of Ministry

by

Vasse1 George Kerr

APPROVAL BY THE COMUITTEE:
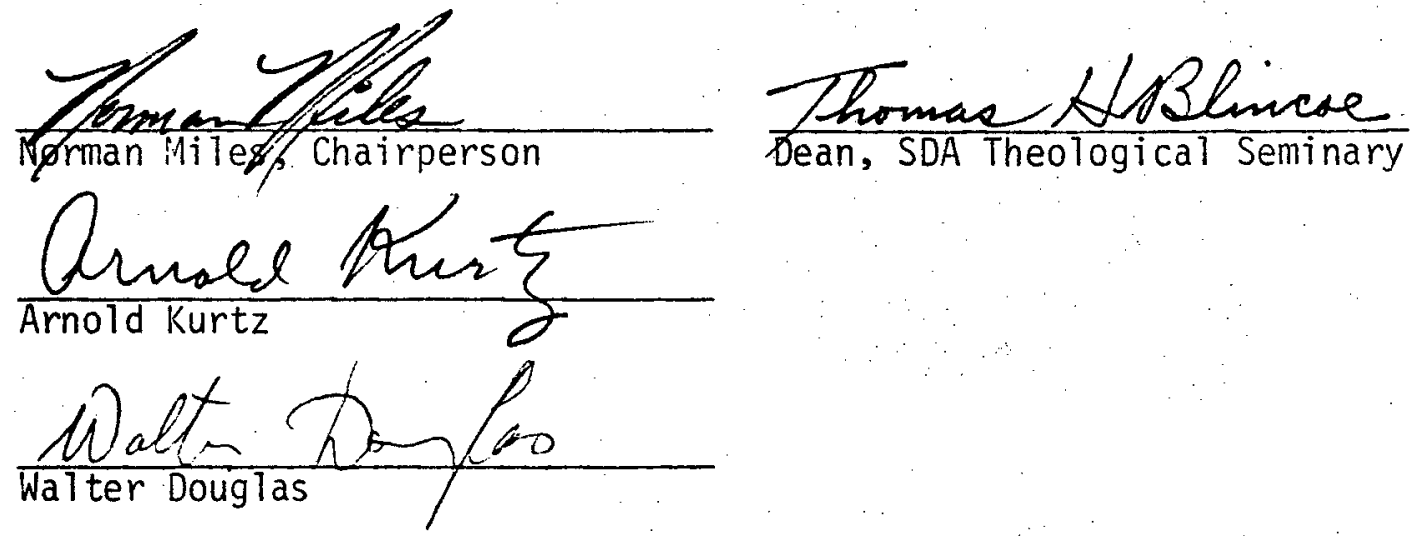

RobertMMohneton

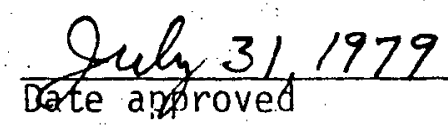


LIST OF TABLES . . . . . . . . . . . . . . . . . .

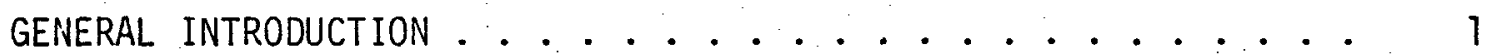

PART I. THEOLOGICAL AND BIBLICAL PERSPECTIVES ON PREACHING

Sections

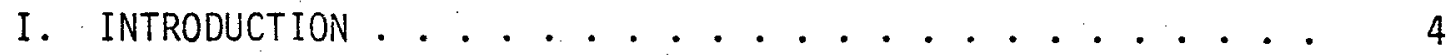

II. SOME BIBLICAL MODELS OF PROCLAMATION ........... 6

An Overview of Some 01d Testament Mode1s . . . . . 6

Deuteronomic Speeches . . . . . . . . . . 7 Jeremiah ................. . 9

Ezekiel .................... 10

Implications for Proclamation . . . . . . . . 13

New Testament Models ............... 15

The Parabolic Models of Jesus ........... 16

Kerygmatic Models in Acts ........... . . 18

Implications for Proclamation .......... 20

Conclusion ................... 22

III. TOWARD AN UNDERSTANDING OF BIBLICAL PREACHING $\ldots \ldots 24$

The Nature of Biblical Preaching . . . . . . . . 24

The Meaning of Preaching in the Bible....... 25

A Brief Survey on Biblical Preaching from the Literature on the Subject ........... 28

Toward a Definition of Biblical Preaching ..... . 33

The Source of Preaching ............. 35

The Content of Biblical Preaching ......... . . 37

The Values of Biblical Preaching . . . . . . . . 41

Conclusion . . . . . . . . . . . . . . 42

PART II. THE CONTEXTUALIZATION OF AN UNDER-

STANDING OF BIBLICAL PREACHING INTO

THE JAMAICAN SITUATION

IV. AN OVERVIEW OF THE AFRO-JAMAICAN RELIGIOUS BACKGROUND . . 45

The Roots of Jamaican Religious Heritage ...... 45 
The People ............... . . . 4 47

The Language . . . . . . . . . . . . . . 48

The Folklore .............. . . . . 49

Present Religious and Political Mood of Jamaica . . . 51

v. COMMUNICATING THE GOSPEL IN THE JAMAICAN CONTEXT .... 56

Preaching as Biblical Storytelling . . . . ... 57

Preaching and Folkculture ......... . 60

Biblical Preaching and Celebration . . . . . . 65

Biblical Preaching and Dialogue ........ 67

Societal Values, the Existential Needs and the Role of Biblical Preaching . . . . . . . . . 72

VI. AN APPLICATION OF THE BIBLICAL MESSAGE WITHIN THE JAMAICAN MILIEU . . . . . . . . . . . . . .

Liberation Theology and the Afro-Jamaican Religious

Experience ................. 84

The Kingdom of God Motif in Jesus ' Parables with

Respect to Jamaica............ 89

VII. SUMMARY AND CONCLUSION ............... 96

Summary ................ . . 96

Conclusion ................ 97

APPENDICES ...................... 100

A--A Paraphrase of Luke 22:54-62 in Contemporary $1 . . .107$

B--A Sample of the Apostolic Kerygma . . . . . . 104

SELECTED BIBLIOGRAPHY . . . . . . . . . . 105 


\section{LIST OF TABLES}

1. Females Fourteen Years of Age and over, Classified by Union Status and Legal Marital Status, $1960 \ldots \ldots \ldots 75$

2. Divorces by Duration of Marriage and Age of Partners at Marriage, $1973 \ldots . . \ldots 76$

3. Number of Divorces Classified by Grounds on which Decree Absolute Is franted and Age of Female Partners at Marriage, $1972 \ldots \ldots . . . . . . .78$

4. Number of Divorces Classified by Grounds on Which Decree Absolute Is Granted and Age of Male Partners at

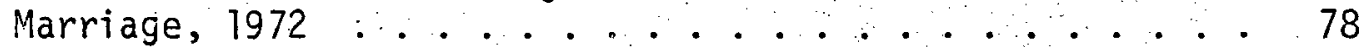

5. A Sample of the Apostolic Kerygma . . . . . . 104 


\section{ACKNDWLEDGEMENTS}

Thanks are extended to those who read and critiqued this research project. Doctors E. Turner, J. Cox, and R. Johnston provided encouraging comments, analys is, and theological insights. Professors $N$. Miles and $W$. Douglas provided insights with respect to the sociocultural climate of the Caribbean. The chairperson of the Doctor of Ministry Program, Dr. A. Kurtz, has always been generous in sharing not only his criticisms but also his encouragement. He carried a major share of this project. I have always left his presence at home or his office encouraged.

Others who at various times have given valuable help which has been greatly appreciated are: Doctors S. Vitrano and E. Chalmers, and Mrs. Vernon Andrews who did the major typing. While Doctor Vitrano did not always agree with everything in this research, his fairness, and above all, the constructive tone of his reactions have meant a great deal to me.

I am grateful to my wife Lola whose comments and patience formed an environment that made this possible.

Finally, without doubt the strongest and steadiest help has come from God. I acknowledge my debt to Him for His guiding hand in this study. This research project is dedicated to my dear wife, Lola, to the Jamaican ministers and above a11, to God. 
Preaching has always been an important function of the Christian church. It is the generating source of the Christian faith, and Paul struck the mark when he declared, "Faith comes by hearing" (Rom 10:17). Martin Luther burnished that mark, making it a hallmark of the Reformation: "Faith is an acoustical affair." The contemporary preacher cannot lose sight of the centrality of the Protestant pulpit. The biblical Keryxon ton logon (preach the word), is a mandate, a command, not a temporary injunction or a recommendation. Not only should the preacher proclaim the Good News, he or she ${ }^{1}$ is to make it relevant to his or her particular culture.

The purpose of this study is to develop a theological grounding for biblical preaching and apply this theological reflection on preaching to the Jamaican situation.

Recognizing that each culture perceives Christ through the spectacles of its own needs, this study will draw upon the religiopolitical, social, and economic background of the Jamaican culture. It will proceed to make relevant the biblical message to this particular milieu.

The study consists of two parts. Part I takes the form of a theological position paper proffering an understanding of biblical

\footnotetext{
${ }^{1}$ In subsequent references the masculine gender alone will be used to refer to both sexes.
} 
preaching. This is further broken down into two sections--first, some biblical models of proclamation and then some attempts toward an understanding of biblical preaching. Part II examines the AfroJamaican religious background and the issues involved in the communication and the contextualization of the Good News into the Jamaican Sitz im Leben. 
PART I

THEOLOGICAL AND BIBLICAL PERSPECTIVES

ON PREACHING 


\section{INTRODUCTION}

This study is based on the evangelical position that the Bible is the authoritative, inspired revelation of God to man. ${ }^{1}$ Not only has God spoken "by the prophets" and "by a Son," 2 but He still speaks to the contemporary mind through scripture. ${ }^{3}$ The Reformation sola scriptura should constitute the fundamental criterion for preaching. This does not exclude the human situation ${ }^{4}$ from authentic preaching, but a "thus saith the Lord" should be the controlling motif of the preaching situation.

Not only should the Bible be the controlling influence of preaching, but it must be interpreted properiy. The preacher needs to heed the advice of Paut to Timothy, "Do your best to present yourself to God as one approved, a workman who has no need to be ashamed, rightly handling the word of truth" $^{5}$ (emphasis mine). This issue becomes crucial in view of the many hermeneutical options available

$1_{2} \operatorname{Tim} 3: 16 ; 2$ Pet $1: 20,21 ;$ John $10: 35$. Unless otherwise indicated, the Revised Standard Version will be quoted throughout.

2 Heb $1: 1,2$

3Rom 15:4.

4The gospel does indeed offer us a new understanding of our Existenz, but it does this because it has an objective word to speak to it. See J. Bright, The Authority of the 01d Testament (Grand Rapids: Baker Book House, 1975), p. 182.

$52 \operatorname{Tim} 2: 15$. 
in preaching. ${ }^{1}$ The preacher should be a skillful and responsible "hermeneutist," which implies that he interprets, proclaims, and translates the word. ${ }^{2}$

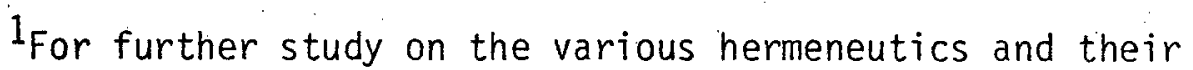
implications with respect to preaching, see Thor Hall, The Future Shape of Preaching (Philadelphia: Fortress Press, 1973), pp. 56-6T; K. Barth, The Preaching of the Gospel (Philadelphia: Westminster Press, 1963), p. 26; E. Brunner, Truth as Encounter (Philadelphia: Westminister Press, 1964); P. T. Forsythe, Positive Preaching and the Modern Mind (Grand Rapids: William B. Eerdmans Publishing Company, 1964), P. 4; D. Grasso, Proclaiming God's Message (Indiana: University of Notre Dame Press, 1968), p. 251; N. F. Pease, "Preaching and Biblical Interpretation," A Symposium of Biblical Hermeneutics (Washington, D.C.: Review and Herald Publishing Association, 1974), pp. 251-262.

${ }^{2}$ This three-fold meaning is found in the New Testament. Johannes Behm, "Hermeneuo,," Theological Dictionary of the New Testament (TDNT), (Grand Rapids: William B. Eerdmans Publishing Company, 1964), 2:661. 
in preaching. 1 The preacher should be a skillful and responsible "hermeneutist," which implies that he interprets, proclaims, and translates the word. ${ }^{2}$

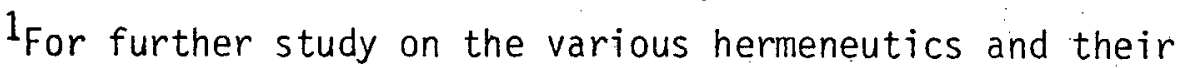
implications with respect to preaching, see Thor Hall, The Future Shape of Preaching (Philadelphia: Fortress Press, 1973), pp. 56-67; K. Barth, The Preaching of the Gospel (Philadelphia: Westminster Press, 1963), p. 26; E. Brunner, Truth as Encounter (Philadelphia: Westminister Press, 1964); P. T. Forsythe, Positive Preaching and the Modern Mind (Grand Rapids: William B. Eerdmans Publishing Company, 1964), p. 4; D. Grasso, Proclaiming God's Message (Indiana: University of Notre Dame Press, 1968), p. 251; N. F. Pease, "Preaching and Biblical Interpretation," A Symposium of Biblical Hermeneutics (Washingtón, D.C.: Review and Herald Publishing Association, 1974), pp. 257-262.

${ }^{2}$ This three-fold meaning is found in the New Testament. Johannes Behm, "Hermeneuo," Theological Dictionary of the New Testament (TDNT), (Grand Rapids: William B. Eerdmans Publishing Company, 1964), 2:661. 


\section{SOME BIBLICAL MODELS OF PROCLAMATION}

The purpose of this section is to isolate some of the biblical models of proclamation. It is not possible within the scope of this research to deal with all the biblical models of preaching; however, a representative sampling is examined. 1

The oid Testament has been greatly neglected as a valuable source for preaching. The position will be taken that it constitutes a part of the revelation of God to man as much as the New Testament and, as such, is a rich source of preaching. For this reason models for proclamation may be drawn from both Testaments.

\section{An Overview of Some 01d Testament Models}

Three examples of 01d Testament models of proclamation are offered. These examples are from the books of Deuteronomy, Jeremiah, and Ezekiel. Focusing particularly upon the saving and liberating

$I_{\text {Of the }}$ 01d Testament models, the books of Deuteronomy, Jeremiah, and Ezekiel have been chosen. Deuteronomy is chosen because it contains sermonic material dealing with the whole life of Israel. It is a book of sermons on the redemptive activity of God. See P. Achtemeier and E. Achtemeier, To Save All People (Philadelphia: United Church Press, 1967), p. 14. Jeremiah and Ezekiel have been selected because the former is a series of prophetic sermons and I would like to focus on Jeremiah's temple sermon; the latter is being used because in a special way, Ezekiel is full of parables and similitudes. Deuteronomy, Jeremiah, and Ezekiel narrated the liberating and mighty acts of God. The parabolic model of Jesus speaks eloquently to our present situation. And of all the New Testament books, Acts seems to give us a clearer knowledge of the early church with regards to the gospel content than any other book. 
acts of God as discussed in these books, the Deuteronomic speeches will be examined first.

\section{Deuteronomic Speeches}

The book of Deuteronomy is not a judicial book per se but was written for the community--the church. It is a proclamation and exposition of the faith of God's people. It is the gospel of the redeeming and liberating God. 1

Deuteronomy can be easily divided into four parts; the first three parts are addresses of Moses, and the last is some appendices. An outline ${ }^{2}$ of the structure is as follows: (1) the first address of Moses--the acts of God; ${ }^{3}$ (2) the second address of Moses--instructions for life; ${ }^{4}$ (3) the third address of Moses--the choice of life or death; ${ }^{5}$ and (4) the appendices--the last acts of Moses, 6 the song of Moses, ${ }^{7}$ the blessings of Moses, ${ }^{8}$ and the death of Moses. ${ }^{9}$

In essence, Deuteronomy presents recitals of the saving acts of God, ${ }^{10}$ teaches the importance of moral principles, and proclaims a loving God, who exists as the most real and perfect being and at the

$1_{G}$. Ernest Wright, "Exeges is of the Book of Deuteronomy," The Interpreter's Bible (Nashville: Abingdon Cokesbury Press, 1953), $2: 312$.

${ }^{2}$ Achtemeier and Achtemeier, p. 15. For a technical analysis of Deuteronomy see J. A. Thompson, Deuteronomy, An Introduction and Commentary (Inter-Varsity Press, 1974), pp. 14-20.

$3^{3}$ Deut $1: 1-4 ; 43$.

4 Deut $4: 44-48 ; 68$.

5 Deut 29:7-30;20.

- ${ }^{6}$ Deut 31 .

7 Deut 32 .

8 Deut 33 .

${ }^{9}$ Deut 34.

$10_{E}$. E. Wright, God Who Acts, Biblical Theology and Recital (London: SCM Press, 1952), p. 70. 
same time has a covenant relationship with His people. At the center of the Good News is the gracious, loyal, and forgiving nature of God-Yahweh is compassionate, gracious, and abundant in Hesed (loving kindness). ${ }^{1}$ Deuteronomy speaks to the spiritual and physical liberation of God's people.

With respect to style, it must be said that the author of Deuteronomy is very direct and forceful; his style has tremendous variations, especially in his "you" and "thou" section. ${ }^{2}$ In many sections the verbs and pronouns are used in the second singular, while in others the second plural is used. The book is personal for it is here that Israel is being addressed. It should be noted also that particular laws are stated in simple form and are followed by exhortation, warnings, and promises. A summary statement on the style of Deuteronomy is apropos here:

In Deuteronomy, a new style of flow and impressive oratory was introduced into Hebrew literature, by means of which the author amplifies his thoughts and cast them into well-balanced classes, varied individually in expressive form, but all bound together by a sustained rnythmic flow. . . In this command of a chaste, yet warm persuasive eloquence, the author of Deuteronomy stands unique among the writers of the 01d Testament. 3

So, the book of Deuteronomy is not only a book of laws and commandments. It is also a book that talks about God in relation to Israel and the contemporary mind. It contains the redemptive

IExod 20:5-6; Num 14:18; Deut $5: 9-10 ; 2 \mathrm{Chr} 30: 1$; Neh $9: 17$, 31 ; Joel $2: 13$; Jonah $4: 2$; Ps $86: 15$.

- 2 Note the "you" and "thou" section: "you:" Deut 1:1-12; 7:6-11; $28: 6-9,29$; "thou:" $5: 621 ; 6: 4-9 ; 7: 12-26 ; 28: 30,31$, etc.

3S. R. Driver, A Critical and Exegetical Commentary on Deuteronomy (New York: Charles Scribner's Sons, 1895), p. 77. 
activities of God. The implications of this will be discussed later.

Jeremiah

The book of Jeremiah is made up of a series of prophetic sermons, with historical and biographical data concerning the last days of the kingdom of Judah. The prophet could well be called the prophet of heart religion. ${ }^{1}$ Systematic theology is not Jeremiah's chief concern, but his burning desire is to be "the spokesman of God to the people of his own day." 2

Jeremiah definitely separates religion from all externalism and makes it a spiritual reality. Religion is of the heart. He is aware of Israel's election and covenant relationship with God, ${ }^{3}$ of the unfaithfulness of Israel, 4 and that the sole remedy for sin lay in sincere obedience. 5 Although he condemns the apostasy of Israel, Jeremiah contemplates its glorious future. His chief concern was a future marked by "spiritual regeneration and moral purification in the lives of the chosen people." 6

The central question of Jeremiah's temple sermon ${ }^{7}$ was, "What gives righteousness?" The answer is not the temple but a moral and

${ }^{1}$ F. D. Nichol, ed., Seventh-day Adventist Bible Commentary, 7 vols. (Washington, D.C.: Review and Herald Publishing Association, 1955), $4: 349$.

2 R. K. Harrison, Introduction to the 01d Testament (Grand Rapids: William B. Eerdmans Publishing Company, 1969), p. 818.

3 Jer $2: 3,21 ; 11: 15 ; 12: 7 f f ; 13: 17$.

4 Jer $5: 1 \mathrm{ff} ; 23: 10 \mathrm{ff} . \quad 5$ Jer $9: 23 \mathrm{ff}$.

6 Harrison, p. 820 . 7 Jer $7: 7-15 ; 26$. 
spiritual relationship with God. There is a sweeping denunciation of priests, people, and false prophets, yet in the end Jeremiah pleads for a moderation of punishment. He said, "I know, 0 Lord, that the way of man is not in himself, that it is not in man who walks to direct his steps. Correct me, 0 Lord but not in just measure, not in Thy anger, lest Thou bring me to nothing." 1

Preachers can emulate the style of this prophet--his message is marked by a tone of controlled earnestness, and in spite of his bitter denunciation and confrontation of the people, he represents God as having pain in His heart for His people. K. M. Yates ${ }^{2}$ points to the close resemblance between the ministry of Jesus and that of Jeremiah.

\section{Ezekiel}

While Jeremiah emphasized the concept of divine immanence, Ezekiel appeared to exemplify the idea of divine transcendence. Of a11 01d Testament prophets, Ezekiel seems a highly developed mystic. The triumph of restoration which he contemplated was summed up in the

\section{Jer $10: 23,24$.}

- 2 Yates notes the following similarities: (1) Both lived under similar world conditions--Rome in Jesus' day and Babylon in Jeremiah 's. (2) Both Jeremiah and Jesus grew up in quiet country places. (3) Each of them came early to be rejected in the home community and by members of the family circle. (4) Neither had the joys and blessings of married life. (5) Each was painfully conscious of God's hand on them. (6) Their methods of teaching were the same. (7) Both wept over their people. (8) Both men's attitudes towards the people were the same. (9) Both had intimate fellowshio with God. (1) Both rejected formalism. (11) Both condeinned the Scribes and Pharisees as blind leaders. (12) Both were considered a failure. Preaching from the Prophets (New York: Harper and Row Brothers, 1942), pp. 125, 136. The prophet speaks of Christ and His righteousness, the heart of proclamation (Jer 23:5,6). 
final words of his prophecy, "Jehovah is there."

When Ezekiel began his ministry the Northern Kingdom of Israel was no longer in existence and the overthrow of Judah was rapidly approaching. The prophet was called to clarify God's purpose for His people in the bitter experience of the Babylonian captivity.

One of the great themes developed in the proclamation of Ezekiel is the moral responsibility of the individual. Harrison comments:

The great contribution of the prophet Ezekiel to the doctrine of man lies in his emphas is upon personal responsibility. The New Covenant (Jer 31:31ff; Ezek 36:26ff) would not exhibit a redeemed society formulated on the basis of individuals who responded to the free expression of divine love.1

Ezekiel did for Israel what all preachers can and should do for their people. Amidst God's chastisement there was held out hope and restoration. "Even in captivity divine justice was seasoned with mercy." 2

It is instructive to take a close look at one of the prophet's sermons in Ezek 20. The substance of this discourse is God's dealings with His people. It includes the acts of God and man's act--God's saving action and man's rebellion. Israel was chosen, not because the people were good, but, God said, "I acted for the sake of My name." 3 This concept of Yahweh acting for the sake of His name is explicit in the book of Ezekiel. ${ }^{4}$ This idea is summed up in the New Testament as "grace."

1Harrison, p. $583 . \quad$ 2Nichol, p. 569.

$3_{\text {Ezek } 20: 9}$

${ }^{4}$ Ezek $20: 14,22,44 ; 36: 21,22,25 ; 39: 25$. 
The Hebrew chen is occasionally translated as "grace" but usually as "favor." It means "graciousness" and "kindness." The closest 01d Testament equivalent is hesed--"loving kindness" or "steadfast love." It is safe to say, therefore, that Ezekiel's proclamation has its basis in the gracious and liberating action of God. It is interesting to note that chapters $31: 1$ to $48: 35$ are prophecies of mercy concerning Israel. Blackwood said:

God deals with His people for His "name's sake" and He will restore them, not because of their merits, but because of His essential nature. He has chosen a people through whom He is revealing Himself to the nations of the world. However, that people may turn aside from His ways, He will call them back.

Ezekiel is earnest and intense in style, and his language is graphic. He uses various parables and similitudes like the vine tree, ${ }^{2}$ the wretched infant and lewd adultress, ${ }^{3}$ the two eagles and the vine, ${ }^{4}$ the sour grapes, ${ }^{5}$ the 1 ion's whelps, ${ }^{6}$ and the wasted vine. ${ }^{7}$. In all of the above figures, the prophet is confrontational. The prophet presents two apparently mutually exclusive extremes. He is not only a poet with imaginative and passionate rhetoric but also a formal priestly author and pioneer of legal and ritualistic Judaism. ${ }^{8}$

Some other biblical models that overlap in relation to some of the models discussed are $2 \mathrm{Kgs} 22$ and 23 on Josiah's reform when the

1A. W. Blackwood, Jr., Ezekiel, Prophet of Hope (Grand Rapids: Baker Book House, 1965), p. 139 .

$$
\begin{array}{lll}
{ }^{2} \text { Ezek 15:1-8. } & { }^{3} 16: 1-63 . & { }^{4} 17: 1-24 . \\
{ }^{5} 18: 1-32 . & { }^{6} 19: 1-9 . & { }^{7} 19: 10-14 . \\
{ }^{8} \text { Otto Eisseldt, } & \text { The 01d Testament, An Introduction, trans. }
\end{array}
$$
P. Ackroyd (Oxford: Basi1 Blackwe11, 1965), P. 382 . 
book of the covenant was found in the temple; Josh 24 on the covenant at Shechem; and PSS 105, 106. Ellen G. White states, "They contain lessons of warning that the people of God in these last days need to study, and should be read at least once every week." 1

\section{Implications for Proclamation}

Upon examination of the models under consideration, certain salient points are obvious for preaching, particularly with respect to the content of proclamation:

1. God condescended in time and space and became the Lord of history. Through this breaking through into history, He has performed His mighty acts in saving Israel. ${ }^{2}$ Proclamation is a narration and a confession of Yahweh's act, and therefore the Bible exists as a confessional recital of His acts together with the teaching accompaning these acts, or inferred from them in the light of specific situations which the faithful confronted. ${ }^{3}$ However, it should be mentioned that preaching is more than narration and confession. There must be interpretation. The preacher seeks to reinterpret the salvation history of God (heilsgeschichte). The saving act of God is in a covenantal setting, the basis of which is God's law. If Deuteronomy is analyzed properly, grace, law, and response are its major tenets.

Not only must the preacher declare and interpret to the

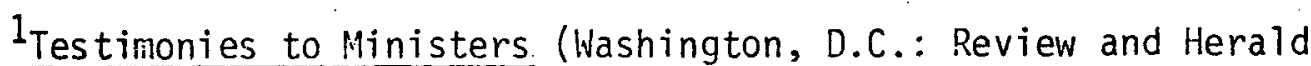
Publishing Association, 1962), pp. 98, 99.

${ }^{2}$ Exod 20:1; Mic 6:5; Ps 78:4; Acts $2: 11$.

3 Wright, p. 85 . 
contemporary minds what God has done and is still doing, but he must preach for a response. Like Moses, the preacher will challenge God's people to "remember," "to relive" God's saving act. ${ }^{1}$ Like Jeremiah and Ezekiel, the preacher will declare his solidarity with God's people and bring hope, revival, and reformation to people. ${ }^{2}$

2. It will be recognized that since God's mighty acts are revealed in the 01d Testament, the New Testament alone cannot conlpletely constitute the biblical material for preaching. Both testaments are necessary. ${ }^{3}$ Furthermore, the 01d and New Testaments testify to Christ like two choirs facing each other in a church and pointing to the same center, to the Mediator between God and humankind. ${ }^{4}$ The serious preacher will see a past event as becoming a present event, the narrative becoming testimony, the testimony becoming the act of God. ${ }^{5}$ The 01d Testament was written "that we and all

$I_{\text {Deut }} 5: 15 ; 6: 12 ; 7: 18 ; 8: 2,14 ; 32: 7$.

2 Ezek 37.

${ }^{3}$ One of the current debates in theology today is the relationship that exists between the 01d and New Testaments. See the following studies on this: Albert Van Ruler, The Christian Church and the 01d Testament, trans. C. W. Bromily (Grand Rapids: Eerdmans, 1971), J. D. Smart, The Interpretation of Scripture (Philadelphia, 1963); B. W. Anderson, ed., The 01d Testament and the Christian Faith (New York: Harper and Row, 1963); C. Westermann, The 01d Testament and Jesus Christ, trans. 0. Kaste (Augsburg House, 1970); Norbert Holfink, The Christian Meaning of the 0ld Testament, trans. R. W. Watson (Milwaukee: Bruce Pub. Co., 1968); G. F. Hase1, 01d Testament Theology (Grand Rapids: Eerdmans, 1975), pp. 105-127.

${ }^{4} \mathrm{M}$. Kuske, The 01d Testament as Book of Christ (Westminster Press, 1976), p. 16.

${ }^{5} \mathrm{~K}$. H. Miskotte, When the Gods Are Silent, trans. With Introduction by J. W. Doberstein (London: Collins. St. James Place, 1967), p. 338 . 
generations might be inspired and led into a personal relationship with, and knowledge of God." 1 This is the purpose of the Bible. This is the goal of all proclamation.

3. It was also discovered in the prophetic models mentioned that preaching is confrontationar. ${ }^{2}$ This confrontation is done with compassion and love, 3 and the modern preacher is called to walk in the prophetic tradition. All evils should be challenged by preachers of righteousness. Moses, Isaiah, Jeremiah, Micah, Amos, and others were brilliant forerunners of this type of preaching.

\section{New Tes tament Models}

The entire Bible can be seen as a divine-human drama, the heilsgeschichte (salvation history) in which God has revealed Himself to people. The 01d Testament is Act I in the drama and the New Testament is Act II. On the stage of history both acts are interrelated. So far some biblical models of proclamation from Act I have been isolated. For further consideration models from Act II will be briefly discussed. The parabolic models of Jesus will be examined first.

The Parabolic Models of Jesus

A look at the historical Jesus as proclaimer would suggest a 1976), p. 5 .

${ }^{1}$ D. F. Hanse, Theology of the 01d Testament (London: SPCK,

${ }^{2}$ Deut 13, 27; Jer 7, 5, 6, 45-51; Ezek 6, 11, 14-15, etc.

${ }^{3}$ Deut $5,7,28,32$; Jer $8: 22 ; 24: 6,7 ; 29: 10-14 ; 31: 37-34$;

Ezek $16: 8-14 ; 34: 25-31$. These are samples of prophetic confrontation in love. 
basic fact: He proclaimed the kingdom of God largely through parables. The word "parable" from the Hebrew Mashal is used for all expressions which contain a comparison to illustrate a general truth. ${ }^{1}$ The Septuagint translated parabole which means "placing alongside of," a comparison. In essence, a parable is a figurative saying.

The parables of Jesus have a common feature. Hunter thinks that "all Jesus' parables have to do, in one way or another, with the kingdom of God." 2 The heart of Jesus' good news is that the kingdom of God is come, ${ }^{3}$ which means that eschatology was at the center of Jesus" proclamation. While Dodd speaks of "realized eschatology, "4 that is, the kingdom has come, Schweitzer's thesis on this is "consequent eschatology," 5 that is to say, the kingdom would arrive soon

$1_{F}$. Hauck, "Parabolēe," TDNT, 5:747. It should also be noted that Mashal and Mathla embrace various categories: mataphor, simile, parable, similitude, allegory, illustrations, etc. J. Jeremias, The Parables of Jesus, trans. S. H. Hook (London: SCN Press, 1954), p. 17.

${ }^{2}$ A. M. Hunter grouped the parables of Jesus in the following ways: (1) the coming and growth of the kingdom (Mark $4: 3-8 ; 4: 26-29$; 4:30-32; Luke 13:18-21; Matt 13:24-30; John 12:24); (2) the grace of the kingdom (Luke $7: 36-50 ; 15: 1-10 ; 15: 11-32 ; 18: 9-14 ;$ Matt 18:23-35; 20:1-15); (3) the man of the kingdom (Luke 14:28-33; Matt 13:44ff; Luke 11:5-8; 18:2-8a; 17:7-10; Matt 7:24-27); (4) the crisis of the kingdom (Luke 12:57-59 cf; Matt 5:25ff; Luke 14:15-24; Matt 25:14-26; Luke 16:1-8; Matt 25:1-12; Mark 12:1-9); (5) eternal issues (Luke 10: 25-37; 16:19-31; Matt 25:31-46; Luke 13:23ff). The Parables Then and Now (London: SCM Press, 1971), pp. 19, 35-121.

\section{Mark 1:15.}

Ac. H. Dodd, Parables of the Kingdom (New York: Charles Scribner's Sons, 1961), pp. 92, 84.

${ }^{5}$ A. Schweitzer, The Quest of the Historical Jesus (New York: McMillan Press, 1968), p. 356. For more detailed treatment on the "kingdom of God" see the following works: 0. Cullman, Christ and Time (Philadelphia: 1964); R. Schnackenburg, God's Rule and Kingdom (New York: N.p., 1963); H. Ridderbos, Coming of the Kingdom (Nuttley, 
in the imminent end of the world. However, while it is true that the reality of the kingdom can be seen in terms of the deeds of Jesus, the eschatological aspects is evident. Jeremias uses the expression "progressive eschatology." 1

One of the essential aspects of Christ's parabolic method is that it recognizes the Sitz im Leben setting. Johnston says, "The rabbinic and Synoptic parables partake of the same genre." In his contrast between rabbinic parables and Jesus', Johnston pointed out that "the parables of Jesus seem intentional to reverse conventional values, while the rabbinic parables are intended to reinforce them." 2 The parables of Jesus should not be seen strictly from the standpoint of morals, as suggested by Julicher who studied the parables through the eyes of Aristotle. ${ }^{3}$ Granskou puts this thought tersely, "Iho could know the Jewish Jesus better than the Jewish rabbi?"4

New Jersey, 1962); T. F. Grasson, His Appearing and His Kingdom (London: N.P., 1955); H. Roberts, Jesus and the Kingdom of God (London: N.p., 1955); Hans Kung, The Church (New York: Image Books, 1976), pp. 69-144; G. E. Ladd, The Presence of the Future (Grand Rapids: William B. Eerdmans Publishing Company, 1974).

1J. Jeremias, The Parables of Jesus, rev. ed. (New York: Scribner, 1963), p. 230. A7so see J. D. Crossan, In Parable, The Challenge of the Historical Jesus (Hew York: Harper and Row Publishers, 1973), p. 24.

2R. M. Johnston, Parabolic Interoretation Attributed to Tannain (Ph.D. dissertation, The Hartford Foundation, 1977), p. 628, 633.

$3_{\mathrm{A}}$. Julicher, The Parables of Jesus (Tubingen, 1910), pp. 25118. For a good summary of Julicher, see J. D. Kingsbury, The Parables of Jesus in Matthew 13 (Richmond, Va.: John Knox Press, 1966), pp. 1-3.

4. M. Granskou, Preaching on the Parables (Philadelphia:

Fortress Press, 1972), n. 22. 
The concept that all parables teach one moral point and that there is a sharp distinction between parables and other categories of speech may not be all of the truth. Bugge, Fiebig, ${ }^{1}$ Dodd, and Jeremias have proven otherwise.

In summary of this section, therefore, one can say that at the core of Jesus' parables is basileia tou Theou: "Indeed He said nothing to them without a parable."2 Attention will now be paid to the Kerygmatic models in the book of Acts.

Kerygmatic Models in Acts

In the Septuagint version of the 01d Testament there are two references to the word Kerygma $^{3}$ and both have to do with the content of proclamation. In the New Testament, the emphasis is also on content, 4 and several scholars ${ }^{5}$ are in agreement with this thought.

1p. Feibig has given a detailed study of the rabbinic parables in comparison with those of Jesus. He maintains that Jesus was closer in style to the Meshalim of the rabbis than the Greek literary theory. Die Gleichinisreden Jesu im Lichte der Rabbinischen Gleichnisse des Neutestestamentlichen Zeitalters/The Parables of Jesus in the Light of the Rabbinic Parables of the New Testament Times/, quoted by Granskou, p. 21 (Tubingden, 1912). Bugge attacked Julicher and his "radical" commentary on the parables, see C. A. Bugge, Die HauptoarabTen Jesu /The Main Parables of Jesus/ (Giessen, 1903), vol. 1 quoted by Granskou, p. 21.

$$
2 \text { Matt 13:34. } \quad 37 \mathrm{Chr} 30: 5 \text {; Jonah } 3: 2 \text {. }
$$

$15: 3-9$.

4 Matt 12:41; Luke 11:32; Rom $16: 25 ; 1$ Cor 1:21;2:4; 15:14;

${ }^{5}$ See R. C. H. Lenski, The Interpretation of St. Paul's First and Second Epistle to the Corinthians (Columbus, Ohio: The Artburg Press, 1943), p: 62; M. R. Vincent, Word Studies in the New Testament, vol 3 (New York: Charles Scribner's Sons, 1924), p. 192. While C. H. Dodd sees kerygma in 1 Cor 15:3-8, Bultmann does not. The former emphasized the objective reality to kerygma, the latter, the nonobjective and dynamic character of the proclamation. Dodd reminds us 
At times the word refers to the function of preaching or to the preaching office itself. ${ }^{1}$

Any serious study on the kerygma in the book of Acts will

have to take into consideration the work of Dodd in The Apostolic

Preaching and Its Development (1936). After examining fragments of the early Christian tradition, Dodd arrived at the following as the apostolic proclamation from the Epistles:

The prophecies are fulfilled, and the New Age is inaugurated by the coming of Chrișt. He was born of the seed of David. He died, according to the Scriptures, to deliver us out of the present evil age. He was buried. He rose on the third day according to the Scriptures. He is exalted at the right hand of God, as Son of God and Lord of quick and dead. He will come again as Judge and Savior of men. 2

From the book of Acts the same writer notes the following as the primitive kerygma:

The age of fulfillment has dawned. This has taken place through the ministry, death and resurrection of Jesus. By virtue of the resurrection, Jesus has been exalted at the right hand of God, as Messianic head of the new Israel. The Holy Spirit in the Church is the sign of Christ's present power and glory.. The Messianic Age will shortly reach its consummation in the return of Christ. An appeal for repentance.

that the gospel should not be "de-historized; Buttmann reminds us that it should not be dogmatized." Both are mutually corrective. For the theological debate on 1 Cor 15:3-8 and Gal 1:8-11, see W. Baird, "What Is the Kerygma? A Study of 1 Cor 15:3-8 and Gal 1:11-17," Journal of Biblical Literature 76 (Philadelphia: Press of Maurice Jacobs, 1975): 182-183. For further study on the word Kerygma see R. Bultmann, Kerygma and Myth, ed. H. W. Barfsch, trans. R. H. Fuller (London: SPCK, 1954); C. E. Braaten and R. A. Harrisville, Kerygma and History: A Symposium on the Theology of R. Bultmann (New York: Abingdon Press, 1962), pp. 25-54; F. Delitzsch, Cominentaries of the 01d Testament Minor Prophets (Grand Rapids: William B. Eerdman's Publishing Company, 1961), 1:404.

$$
\begin{aligned}
& 12 \text { Tim 4:17; Titus } 1: 3 . \quad 2 p .17 . \\
& \text { 3Ibid., pp. 21-24. }
\end{aligned}
$$


From a close look at the five speeches in the book of Acts ${ }^{1}$ and 1 Cor 15:3-8, it is clear that the very crux of the apostolic preaching is Christ who broke through into history. However, it does not mean that every sermon preached in the New Testament contains all the elements Dodd mentioned, but the essential ones will be present. Kereygmatic proclamation is essentially the accomplishment of man's salvation and an interpretation of that event within the contemporary situation. The saving act of God is seen in the Kerygma. It is the unique and divinely ordained medium for conveying this saving activity of God. Although rooted in the past, it can be experienced only in the present. As long as people are by nature enslaved to evil, so long will the Kerygma be vitally relevant to his greatest need. 2

\section{Implications for Proclamation}

Since the parables of Jesus are kingdom oriented, people are called to "repent, and believe in the gospel." 3 The concept of the coming kingdom was not new in the Jewish thought. This was central in Christ's preaching. The euaggelion, the good news, is that the kingdom of God is at hand, or has come. Preachers are challenged to declare God's kingdom (His kingship, rule, and authority). Not only the listeners but also the preacher should submit to the lordship of

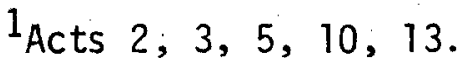

- 2R. M. Mounce, The Essential Nature of New Testament Preaching (Grand Rapids: William B. Eerdmans Publishing Company, 1960), o. 156. 3 Mark $1: 15$. 
Christ. It is easy to proclaim the Annointed One without proclaiming Him as Lord. Luke says that "God has made Him both Lord and Christ"1 (emphasis mine).

Man must "seek first His Kingdom and His righteousness"2 and must pray. "Thy Kingdom come." 3 God rules in the lives of preacher and people, and His ruling makes a radical difference; the preacher presses home the joy of forgiveness and liberty in God's kingdom, both present and future.

A further implication to proclamation with regards to Christ's parables is the fact that Jesus made use of His environment in order to be effective. The Germans called this the Sitz im Leben Jesu. So preachers, while they will not allow their contemporary situations to decide the content of their message, they will avoid preaching out of context. In other words, interpretation and relevancy are two of the key issues in the task of proclamation.

A brief examination of the Kerygmatic models in the book of Acts is appropriate. In brief, the Kerygma is the death, resurrection, and exaltation of Christ. The Kerygma declares that Christ died for our sins. Therefore, people can be put back into a right relationship with God. Righteousness by faith is implied in the Kerygma; and this is strictly Paul's contribution to the Kerygma. Christ as the Paschal lamb that was slain is Peter's contribution. The preacher presses home the forgiveness of God in Christ, and the believer is passed from death to life, from bondage to freedom.

$1_{\text {Acts } 2: 36 \text {. }}$

2 Matt $6: 33$.

3 Matt $6: 10$. 
The Kerygma also declares that Christ has been resurrected and has become a guarantee, a pledge of those who are asleep in Christ. The preacher brings hope to the believer through the resurrection. The Kerygma teaches the exaltation of Christ at the right hand of God. of the many implications for preacher and people, one is that the church need not be an orphan in this world. The body of Christ can be hopeful, in that One who walked this earth is at the right hand of Majesty.

These are some of the possible implications of the parables of Jesus and the Kerygma in the book of Acts. God's reign should be recognized not only in the lives of people but also in the earth. With respect to the Kerygma, man's salvation has been achieved and the preacher is called to declare this freedom in Christ.

\section{Conclusions}

I have attempted to isolate some biblical models of proclamation which can serve as a guide to preachers. It has been pointed out that both the 01d and the New Testament constitute authentic models for proclamation. In the former, God's redemptive deeds are made manifest. He has demonstrated His mighty saving power on behalf of His people. In the latter, God's love is seen in Christ.

The Christian preacher is called to narrate and re-interpret this self-disclosure and love of God to the modern mind, and this task of preaching is urgent and relevant. It is urgent in that eternal issues are at stake--the salvation of people and the vindication of God's character. It is relevant because the gospel constitutes the answer to people's spiritual and moral problem--sin. 
In the task of proclamation the preacher is to preach Christ in all His glory, in His exemplary life on earth, His death, resurrection, His work in the sanctuary, and His parousia (coming). Authentic proclamation will begin at the epiphany and end at the parousia.. This is the peril and glory of preaching as seen in two of Paul's declarations. "For necessity is laid upon me if I do not preach the gospel."1 "For I am not ashamed of the gospel: it is the power of God for salvation."?

$1_{1} \operatorname{Cor} 9: 16$.

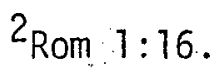




\section{TOWARD AN UNDERSTANDING OF BIBLICAL PREACHING}

In order to arrive at an understanding of biblical preaching one needs to consider some of the essential elements of biblical preaching such as its nature, source, content, and values.

\section{The Nature of Biblical Preaching}

While the Bible is not a book of defnintions, it is a thesaurus of words on preaching in which one can find a large number of terms describing different aspects of what the preachers were doing when they preached. In the following paragraphs six Greek words ${ }^{1}$ in

1 The words to be dealth with are as follows: Paraklein is translated "exhort" in the Revised Standard Version (1 Tim 4:13); Plerein has the meaning "to fill," "to fill up," as for example, a vessel or a hollow place. See E. Robinson, A Greek and English Lexicon of the NT (New York: Harper and Brothers, Publishers, 1885), p. 590. LaTein means "to speak," that is, "to use the tongue of faculty of speech," "to utter articulate sounds;" cf. 1 Cor 14:11; Matt 9:33; 12:22; 15: 31; Luke 11:14; Rev 13:15. See also J. H. Thayer, A Greek-English Lexicon of the New Testament (New York: American, Book Company, 1886), p. 368. In the Septuagint, the equivalent of bisśar means "to bring good news," "to announce glad tidings." Bifśsar is used in the 01d Testament for any kind of good news: 1 Sam $31: 9 ; 2$ Sam 1:20; 1 Chr 10:9; of the joyful tidings of God's kindness: Ps $39: 10$; to soterion theou, Ps 95: 2 ; in particular, of Messianic blessings: Isa $40: 9 ; 60: 6 ; 61: 1$, etc. In the New Testament it is used especially of the glad tidings of the coming of the kingdom of God and of the salvation to be obtained in it through Christ. Kataggellein means. "to set forth," "to articulate." (Thayer, p. 256). The KJV has "to preach," while the RSV has "to proclaim." This word can be located in the following texts: Acts 4:2; 16:17; $17: 3,23 ; 26: 23$; 1 Cor $2: 1 ; 9: 14$; Phi1 1:16, 17; Col 1:28. Kérussein is "to cry," "to proclaim as an herald (Robinson, p. 381). In the Greek 01d Testament kërussein occurs thirty-three times, and there is no single Hebrew equivalent. In Hos $5: 8$; Joel $2: 1$; Zeph $3: 14$; Zech $9: 9$, 
the New Testament with special emphasis on their possible implications for preaching will be briefly examined.

The Meaning of Preaching in the Bible

Paraklein expresses the close relation of preaching to the ministry of the Spirit (Paraclete). This verb and its noun form parakles is may be traced to the saving work of the triune God which leads those in need of spiritual help to the Son of God. It is preaching with exhortation in the power of the Holy Spirit. 1. Paul Eppinger holds that preaching in the sense of paraklein is preaching the word in exhortation and with encouragement. ${ }^{2}$ The preacher is challenged to have an urgent and personal concern for people as he presses home the claims of the gospel. At Pentecost the hearers cried, "What shall we do?" Peter, with deep concern, "testified with many other words and exhorted. . . "3 The preacher does not adopt a take-it-or-leave-it attitude in his presentation of the gospel. Like Christ, he pleads with people to come to Him, "all who labor and are heavy laden, ..."4 In commenting on the word paraklein, weatherspoon said:

Kērussein is used for $\sqrt{\text { rwc }}$, "to make a noise, "to exalt." In Exod 36:6 and $2 \mathrm{Chr} 36: 22$ it is used for hä cá bir qō7; in Jonah $3: 7$ for $\sqrt{z^{\circ} q}$; in 2 Chr 24:9 for nätan qöl; in Dan 5:29 (Theodotian version)

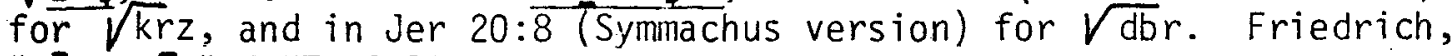
"Kērussō," TDNT, 3:700.

1Schmitz, "Parakaleō," and "Paraklesis," TDNT (1976), 5:799

2"Be Occupied with Praaching," Christianity Today 18. (June 1967): 113-114.

3Acts $2: 40 . \quad 4$ Matt $11: 28$. 
Exhortation makes articulate the quality of "a knock on the door," the "note of summons" which is implicit in every presentation of truth. It is not enough to say that truth makes its own appeal. It does indeed, but the preacher must be more than a transmitter, he must be truth's advocate.

The word plērein was used to describe Paul's preaching before the Romans, "I have fully preached the gospel of Christ." 2 Paul had a great burden to proclaim the good news and consequently he carried out his job as a preacher completely. Like Paul, everywhere the preacher goes there should be centers from which Christianity will spread. 3

Preaching in the biblical sense is not the delivery of discourses, but rather a face-to-face, person-to-person speech. Lalein carries this meaning and implies that there should be personal warmth between pulpit and pew, in what Buber calls the "I-Thou relationship."4 First person references like "you," "we," "my," "our," and "I" should be prominent in the preacher's messages. There will be a personal relationship between preacher and people in the understanding of the nature of preaching, and the Good News needs to be enunciated clearly.

The preacher, to be effective, must "set forth"--"articulate"-(kataggellein) his message (euaggelion). This calls for clearness of

1J. Weatherspoon, Sent Forth to Preach (New York: Harper and Brothers, 1954), p. 75.

${ }^{2}$ Rom 15:19.

3. Sandy and A. C. Headlam, A Critical and Exegetical Commentary on the Epistle to the Romans (Edinburgh: T \& T CTarke, 195E), p. 409 .

$4_{M}$. Buber, I and Thou, A New Trans. with a Prologue "I and You" and Notes by W. Kaufmann (New York: Charles Scribner's Sons, 1970). See also H. Farmer, The Servant of the Word (London: Nisbet and Company, 1946). 
speech and emphasizes the importance of voice culture and the study of grammar. In the word euaggelizein, the prefix eu ("wel1," "good") takes on special meaning. The preacher is a bearer of good news. He joins with the angel in proclaiming "great joy which will come to all the people." 1 Indeed, the Good News is here already in Christ. The preacher must be ready to evangelize a world that is in need of the light of the gospel.

It is impossible to get a clear view of the nature of preaching wi thout an understanding of kērussein. This word is seldom used in describing the proclamation of the prophets, but in the New Testament kërussein ${ }^{2}$ denotes the declaration of an event with emphasis on the action.

The mission of Jesus Christ, and the chief object of preaching, were kērussein. ${ }^{3}$ Not only was proclamation the task and mission of Jesus but it was also that of John the Baptist who heralded the Messianic age, ${ }^{4}$ of the disciples who preached that men and women should

1Luke 2:10.

20ne can note four things about kērussein: (1) it is usually action (Matt 24:14; 26:13; Mark 13:10; 13:19; Luke $12: 3 ; 24: 47$; 1 Cor $1: 9$; Col $1: 23$; 1 Tim 3:6); (2) usually the content is denoted by a substantive in the accusative, e.g., polla in Mark 1:45; auton referring to Moses in Acts $15: 21$; (3) the person to whom the preaching is addressed is always in the dative, autois in Acts 8:5 and allois in Luke $4: 18$. etc.; (4) the place at which the proclamation occurs is indicated by a preposition, usual1y en (Matt 3:1; Mark 5:20), en te Dekapolei (Matt 11:1). See Friedrich, TDNT, vol 3.

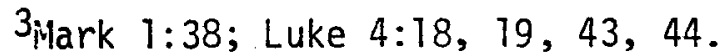

4 Mark $1: 4$; Matt $3: 1$; Luke $3: 3$. 
repent and that the kingdom is at hand, 1 and of the apostles who proclaimed Christ. 2

Relating the concept of kërussein to the modern preacher, the implication is that Christ's followers today are called to stand in the preaching tradition of Jesus and His followers. They are called to herald Christ, to participate in the extension of the incarnation in which "the transfiguration of the cross and the resurrection from ancient facts of a remote past becomes a living reality" ${ }^{3}$ to the contemporary mind.

Having examined the meaning of preaching in the Bible and its implications for the preacher, a brief survey of biblical preaching. from the literature on the subject is presented, following which a personal definition of biblical preaching is offered.

\section{A Brief Survey of the Literature on the Subject of Biblical Preaching}

In the past an effort to proclaim the Good News of Jesus Christ has been referred to as expository preaching. Recently the expression "biblical preaching" appears to be the more accepted term. Different writers have expressed their personal views on biblical exposition. Whitesell summarized five categories of opinions existing among preachers as to what constitute biblical preaching.

1 Mark 6:12; Matt 10:17.

2 Cor $1: 18,22 f f ; 2: 4 ; 2$ Cor $4: 5 ; 5: 19$.

3D. G. Miller, Fire in Thy Mouth (Nashville: Abingdon Press, n.d.), p. 17 . 
1. Some of them think of expository preaching as a series of sermons through a book of the Bible (William M. Taylor, F. B. Meyer, Charles R. Brown).

2. Other men distinguish expository preaching from textual preaching by the fact that it discusses a passage longer than two or three verses (A. Blackwood, D. M. White, P. T. Forsyth).

3. Other authorities bear down on the idea that expository preaching is mainly explanation of the Scriptures (J. A. Broadus, D. G. Barnhouse, H. Jeffs, A. Phelps).

4. There are those who believe that the way in which the Bible passage is handled determines whether or not it is an expository sermon. It appears as the product of exegesis without exhibiting it. and differs from topical and textual sermons in that all is derived directly from Scripture, using more of its details (Whitesel1, G. Campbell Morgan, D. Martin, Lloyd-Jones, M. F. Unger).

5. And there is the view that any preaching drawn from the Bible is expository preaching. D. G. Miller insists that "the substance of one's preaching should be drawn from the Bible. Granted this premise, then it follows that all true preaching is expository preaching, and that preaching which is not expository is not preaching. "1

In addition to the various opinions on what constitute biblical expository preaching, Whitesell negatively defined expository

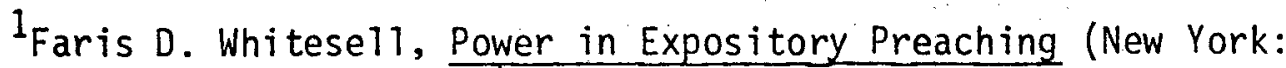
Fleming H. Revell Company, 1963), pp. 8-13. 
preaching. According to Whitese11, expository preaching is not:

1. Running commentary from word to word and verse to verse without unity, outline, and persuasive drive

2. Rambling comment and off-hand remarks about the passage apart from thorough exegesis and logical order

3. A mass of disconnected suggestions and inferences based on the surface meaning of the passage but not sustained by a depth-andbreadth study of the text

4. Pure exegesis, no matter how scholarly, if it lacks theme, thesis, outline, and development

5. A mere structural outline of the passage with a few supporting comments but lacking rhetorical and sermonic elements

6. A topical homily using scattered parts of the passage but omitting discussion of other equally important parts

7. A chopped-up collection of grammatical findings and quotations from commentaries without fusion into a smooth, flowing, interesting, and compelling message

8. A Sunday school lesson discussion of a Bible passage organized around a content outline, informal and fervent, but lacking sermonic and rhetorical factors

9. A Bible reading which links together a number of scattered Bible passages around a common theme but does not deal with any of them in a thorough, grammatical manner

10. The ordinary devotional or prayer meeting talk which combines running commentary, rambling remarks, disconnected suggestions, and personal reactions into a semi-inspirational discussion, but 
without benefit of basic exegetical contextual study and the persuasive element of a sermon. ${ }^{1}$ Knox suggests that biblical preaching, ". . remains close to the characteristic and essential biblical idea, the event of Christ; answers to and nourishes the essential life of the church and it is preaching in which the event in a real sense is recurring." 2

In an attempt to present the word of God, the preacher should bear in mind that each sermon should be seen in the light of the entire revealed will of God. The sermon cannot be an isolated event. According to Hall:

By expository preaching we mean that in which a minister, having by the aid of grammar, dictionary and proper helps, learned for himself what meaning the Holy Ghost intended to convey in the passage he has in hand, and that what uses he ought, in harmony with the rest of divine teaching to make of it, and having filled his own understanding, and warmed his own heart with this truth, tells it to his people with clearness, simplicity, force and fervor. 3

It seems that one of the tests of an expository sermon is not necessarily the length of the text or even the method employed, but rather what happens to it. Expository preaching is that whose chief purpose is to set forth, that is, to instruct, to interpret, and to apply the Scriptures themselves. Its major emphasis is upon the central truth contained in the original intention of the author

1 Ibid., pp. vii, viii.

2J. Knox, The Integrity of Preaching (New York: Abingdon Press, 1957), pp. 19-23.

3John Hall, God's Word through Preaching (New York: Abingdon Press, 1957), p. 24. 
rather than the pre-conceived opinions of the preacher superficialiy supported by biblical methods. One distinct characteristic of true biblical expository preaching is that the message of the Scripture leads the preacher and gives him his directions, rather than the preacher leading the text in his chosen direction. ${ }^{1}$

On the positive side, Whitesell has said of biblical preaching:

1. It is based on a passage in the Bible, either short or long.

2. It seeks to learn the primary, basic meaning of that passage

3. It relates that meaning to the context of the passage

4. It digs down for the timeless, universal truth stemming out of the passage

5. It organizes these truths tightly around one central theme

6. It uses the rhetorical elements of explanation, argument, and application to bring the truth of the passage home to the hearer

7. It seeks to persuade the listener to obey the truth of the passage discussed. ${ }^{2}$

In the opinion of the selected preachers, biblical preaching is the revelation of the whole gospel mediated through the Bible and

\footnotetext{
$I_{L}$. M. Perry, "Trends and Emphases in the Philosophy, Materials, and Methodology of American Protestant Homiletical Education as Established by a Study of Selected Trade and Textbooks Published between 1834 and 1954" (Ph.D. dissertation, Northwestern University, 1961), pp. 400, 401.

2Whitese11, Power in Expository Preaching, p. xv.
} 
a declaration of this gospel in a responsible way to people.

\section{Toward a Definition of Biblical Preaching}

In biblical preaching the preacher, under the Spirit's

guidance and through study, enables the biblical revelation of God in Christ through Scripture to speak to the contemporary situation, thus effecting change in both preacher and people. This definition recognizes certain elements in the whole preaching situation--the Holy Spirit, the human situation, the source and content of preaching. The first two elements will be considered presently and the latter in subsequent sections.

Biblical preaching takes into consideration the human situation. In order for proclamation to be operative and true to its nature, it should have a point of contact. Joseph Sittler speaks of the "ecology of faith." 1 This human milieu is in terms of church and world.

Preaching has several dimensions. It is ecclesiastical. ${ }^{2}$ It takes place in the church which is commissioned to preach. ${ }^{3}$ The preacher needs the support of corporate conviction; he seeks a degree

$1_{B y}$ "ecology of faith," Sittler means the mutual relationship that exists between the preaching situation and the environment. See J. Sittler, The Ecology of Faith (Philadelphia: Muhlenberg Press, 1961), p. $4 f f$.

${ }^{2}$ Grasso gives six ecclesiastical dimensions of preaching: preaching belongs to the church, (2) preaching gives origin to the church, (3) the church can interpret the message of Christ, (4) preaching develops the church, (5) preaching develops a consciousness of community, (6) preaching occurs in the church. D. Grasso, pp. 117-119.

3 Matt 28:18-20; Mark 16:15. 
of congregational solidarity from the body of Christ. C. Morris says, "A preacher not only preaches to a congregation, he preaches out of it. There can be no word of God without the people of God. The living word issues from a living community. "1 0 ne must properly analyze and understand the congregation which is addressed. Taking the congregation out of context is as much a violation of the word of God as taking the Scripture out of context. ${ }^{2}$ Preaching, therefore, must be seen in the light of the church.

In addition to the ecclesiological aspect of preaching is its relationship to the world. 'It takes place amidst people's brokenness. There is a "worldliness" ${ }^{3}$ with respect to preaching. The cross of Christ was raised "outside the gates." 4 His stauros (cross) was a "worldly" one. Proclamation cannot be stripped from its secularity, for the incarnation took place in this world. ${ }^{5}$ God's self-disclosure in Christ ${ }^{6}$ was more than a "transitus" experience, rather, He tented among us. The language of the Good News is of necessity secular. 7

$I_{C}$. Morris, The Word and the Words (Nashville: Abingdon Press, 1975), p. 46.

2F. B. Craddock, As One without Authority (Oklahoma: The Phillips University Press, 1974), p. 130.

${ }^{3}$ For further study on the worldliness of preaching, see C. Fant, Bonhoeffer: Worldly Preaching (New York: Thomas Nelson PubTishing, 1975); D. Bonhoeffer, Letters and Papers from Prison, ed. E. Bethage (New York: The Macmi 17an Company, 1964), p. 200; J. Woelfel, Bonhoeffer's Theology, Classical and Revolutionary (Nashville: Abingdon Press, 1970).

4 Heb 13:12. $\quad 5_{\text {John }} 1: 14 . \quad 6_{2}$ Cor $5: 19$.

For Ritschl, the worldly and human language of the sermon, of the saving and judging word of God is the strongest and most direct way in which the living Christ confronts us. See D. Ritsch1, A Theology of Proclamation (Richmond: Knox Press, 1960), p. 56. 
One of the preacher's tasks, then, is to understand the human situation in the church and the world.

Not only does biblical preaching take into consideration the human situation, but it is also closely related to the Holy Spirit. It is the efficiency of the Holy Spirit that makes the ministry of the word effective. ${ }^{1}$ It is the Holy Spirit, the Great Communicator, ${ }^{2}$ who takes the risen Christ out of the realm of mere ideas and history, and makes Him a present reality to the consciousness of the believer. 3

If one looks through the New Testament, especiality the book of Acts, one sees how the preachers were under the control of the spirit. Philip joined the Ethiopian eunuch through the Spirit; ${ }^{4}$ the Spirit guided Peter to meet Conelius; ${ }^{5}$ the church at Antioch was directed to separate Paul and Barnabas; 6 Paul went to Macedonia; and he was warned of the dangers that awaited him at jerusalem. ${ }^{7}$ The clear implication is that the preacher will be under the influence of the Holy Spirit. The moral quality of his life should be in harmony with his sacred task.

\section{The Source of Preaching}

In biblical preaching the assumption is that the message shall

lEllen G. White, Gospel Workers (Washington, D.C.: Review and Herald Publishing Association, 1948), p. 154.

2E. D. Whitese11, Power in Expository Preaching (Fleming Revel1 Company, 1953), p. 139.

$3_{B}$. Ramm, The Witness of the Spirit (Grand Rapids: William B. Eerdmans Publishing Company, 1960), p. 20.

$$
\begin{array}{ll}
{ }^{4} \text { Acts } 8: 29 . & { }^{5} \text { Acts } 10: 19 ; 11: 22 . \\
{ }^{6} \text { Acts } 13: 2 . & { }^{7} \text { Acts } 16: 6 ; 20: 22-23 .
\end{array}
$$


be from outside the preacher. It is extra nos. ${ }^{1}$ Although preaching must be channeled through personality, the Bible constitutes the authentic source of the preacher's message.

The preacher stands in good company in using the Bible as his source for preaching. Though divine, Jesus did not communicate the will of God to man, as He perceived it, directly to people. He made use of the Scriptures. ${ }^{2}$ Not only were the Scriptures a source of preaching with Christ, but they were the touchstone of His entire 1ife. This was also true of His disciples. It is important that the Bible become the source of preaching because it holds the answer to people's spiritual and moral problems.

In preaching the Bible stands as an indispensable element and it makes intelligible the final outcome of the drama in the plan of salvation. Miller comments:

We claim uniqueness for the Bible and plead that true preaching can have no other source than the witness which the Bible bears to the divine redemptive action. The Bible is the fountain of its faith, and the church cannot expect rivers of living water to flow from its pulpits unless these draw primarily and continually on the fountain. . . If we, therefore, would speak to men in the name of God, which alone is true preaching, we must speak out of the Bible. . . . Our toil must be in the Scriptures, for it was these that were "written that (man). may believe that Jesus is the Christ, the Son of the living God, and that believing/they/ may have life in His name" (John 20:31). Our pulpits are given us to

lpinnock sees the Christ event as taking place outside of us (extra nos) and for our sakes (pro nobis). The existential dimension is the result of the factual and depends on it. See C. Pinnock, Biblical Revelation, the Foundation of Christian Theology (Chicago: Moody Press, 1971), p. 222.

${ }^{2}$ Lev 19:18; Matt $5: 17 ; 22: 37-40$; Luke $4: 16-18,20-21 ; 24: 32$. 
preach from the Bible. If we fulfill this high privilege, we may leave the results with God. 1

\section{The Content of Biblical Preaching}

The saving act of God in Christ, not people's opinion, must be preached. Preaching exists only on the grounds of what God has done in Christ. Barth once lamented that "preachers too often indulge in secondary utterances." 2 The human crisis $^{3}$ (the problem of $\sin$ ) demands the kerygma be preached. Anything less than this does injustice to the gospel, the preacher, and the listeners.

The human predicament demands the abundant grace of Christ. There is a paradigm in the book of Romans ${ }^{4}$ in which Paul sketches the human crisis that Palmer chooses to call the cumulative crisis. ${ }^{5}$ It is cumulative in that there are broken relationships: (1) relationship with God; ${ }^{6}$ (2) human self-understanding, relationship with himself $;^{7}$ (3) the relationship of a man or woman to the

1D. G. Miller, Fire in Thy Mouth (Nashville: Abingdon Press, 1954), pp. 41, 42, 62. Luccock comments on some of the things that are true of preaching which finds its chief source in the Bible: (1) Such preaching speaks in the common language, the native tongue of the Christian church. (2) The Bible contains the most vivid, dramatic, and arresting material the preacher can use. (3) Preaching from the Bible saves us from the futile strain of trying to preach a "great" sermon. (4) The parallels which it affords present experience. (5) The Bible is an unrivaled spring of variety and freshness. See H. Luccock, On the Minister's Workshop (Nashville: Abingdon Press, 1944), pp. $157-163$.

${ }^{2} K$. Barth, The Word of God and the Word of Man, trans D. Horton (New York: Harper and Brothers, Publishers, 1957), p. 111.

- 3Gen 3; Rom 6:23. 4Rom 1:18-23.

${ }^{5}$ E. Palmer, Salvation by Surprise (Texas: Word Books, Publishers, 1975), pp. 35-56.

$$
{ }_{\text {Rom } 1: 20-25 . \quad 7 \text { Rom } 1: 24-26}
$$


rest of the created order. ${ }^{1}$ Because of these broken relationships, Apokaluptetai gar orge Theou ${ }^{2}$ (for the wrath of God is revealed ...). Note the deterioration in the human crisis in a descending order. ${ }^{3}$

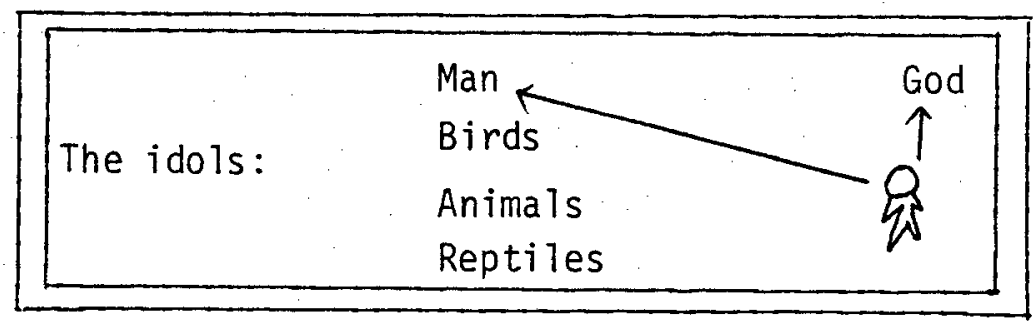

Paul gives the answer to the hunan crisis, diakaiosune Theou Pephanepotai $^{4}$ (the righteousness of God has been manifested). This is cumulative grace. ${ }^{5}$ Briefly, the first Adam was condemned to die, but the second Adam provided life. A diagram may help to explain this ${ }^{6}$ (see page 39 ).

In discussing the content of preaching, one needs to inquire whether this content is the same as that of teaching or if there is a

$1_{\text {Rom } 1: 28-32 .} \quad 2$ Rom $1: 18$.

3 Diagram adapted from Palmer, p. 38.

$4_{\text {Rom } 3: 21 \text {. }}$

${ }^{5}$ Rom 3:21-31. Three themes emerge within these few sentences: (1) The total adequacy and completeness of God's redemption of man is affirmed. (2) Because of the greatness of this redemption there occurs on the side of grace, a leveling of humanity as whole and total as was the case on the side of judgment $(1: 18-3: 20)$. (3) Therefore the immensity of God's redemptive act requires of men and women only faith--an obedient faith; to add one further ingredient ignores the fact of the leveling and diminishes the gift of God (Palmer, p. 52).

6 Diagram adapted from Palmer, p. 64. 


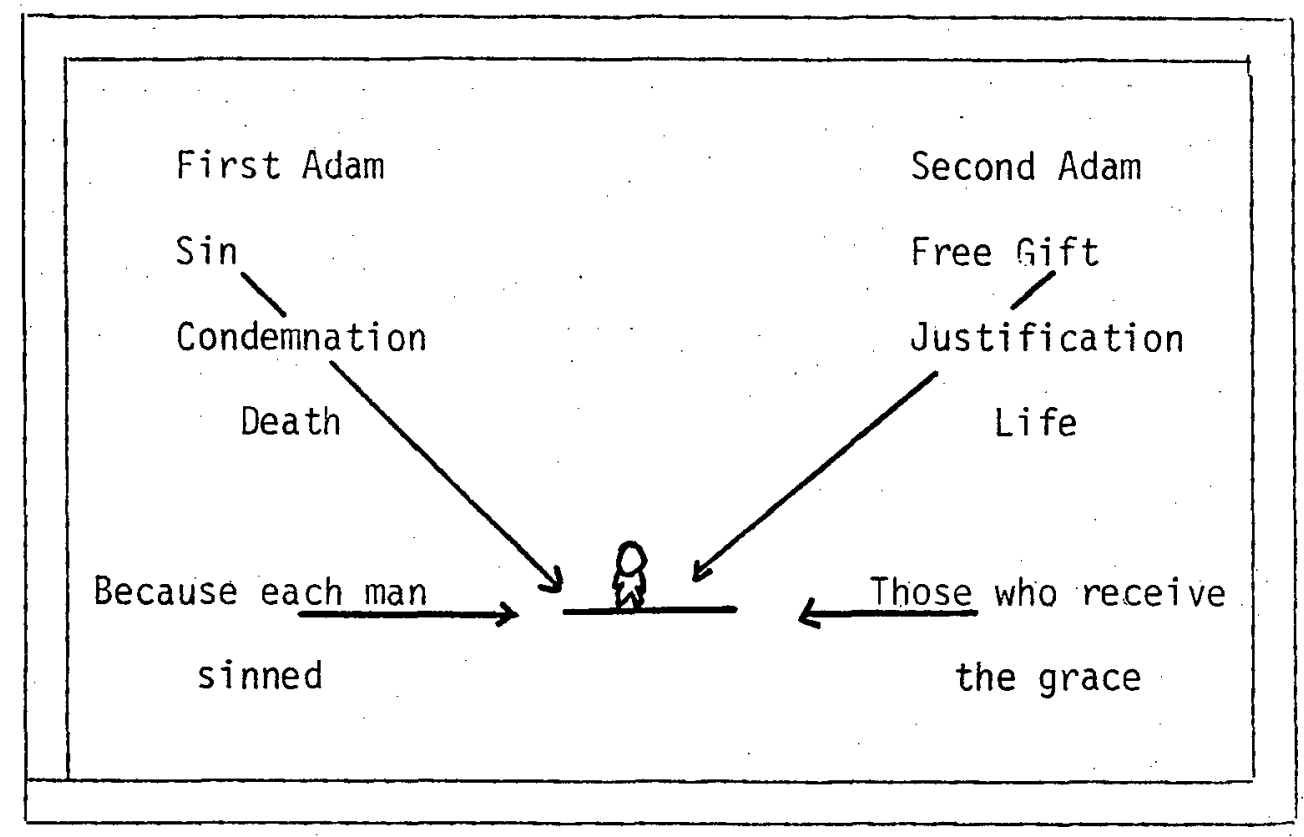

distinction between kerygma and didache. Considerable attention has been given to the relationship between kerygma and didache. Dodd ${ }^{1}$ has made a clear distinction between them, and while "in fairness it should be mentioned that Dodd everywhere assumes the dependence of kerygma upon the didache, "2 he still maintains the separation. Dodd's thesis is that didache came as a result of the delayed parousia, and that while didache is moral instruction, kerygma is theological

1C. H. Dodd, The Apostolic Preaching and Its Development (New York: Harper and Row, Publishers, 1964), p. 7.

2Mounce, p. 41. 
proclamation. Worley, ${ }^{1}$ Furnish, 2 and other scholars ${ }^{3}$ are opposed to

Dodd's views.

What does the New Testament have to say about this issue?

Looking at the New Testament it becomes clear that preaching and teaching are closely related. 4 while it is true that both are different in function, their content is the Good News, and they have the same goal in view--to demand an obedient response to the gospel.

Worley wrote a dissertation "Teaching and Preaching in the Earliest Church" as a reaction against Dodd's work on the distinction between preaching and teaching. See R. C. Worley, Preaching and Teaching in the Earliest Church (Philadelphia: Westminster Press, 1946), pp. 20-86.

2 Furnish states that it is misleading to use the term didache as a designation for moral instruction as contrasted with theological proclamation. The term in itself means only "that which is taught," and this may be theological doctrine as well as moral instruction. See V. P. Furnish, Theology and Ethics in Paul (Nashville: Abingdon Press, 1968), pp. 106-171.

3 Ragnar Asting argues that Acts $5: 42$ does not refer to a double activity in the Early Church. He subordinates preaching to teaching according to his explanation of Luke 20:21. He says: "Christ taught the people in the temple, and his teaching activity consisted of a divine eschatological salvific proclamation"--R. Asting, Die Verkundigung des Wortes in Urchristentum /The Proclamation of the Word in the Early Church/ (Stuttgart: W. KohThammer, 1939), pp. 330-340. R. N. Flew maintains that the primitive tradition is a combination of teaching and preaching. See Flew, Jesus and His Church (Nashville: Abingdon Press, 1938), pp. 154-155. K. Stendahl seeks to clarify the dichotomy between the content of preaching and teaching. See Stendahi, Kerygma und Kerygmatisch: von Zweidentigen Ausdrucken der Predigt der Urkirche und Unserer ("Kerygma and Kerygmatic: Concerning the Double Sense Expression of the Preaching of the Primitive Church and Ours"), Theologische Literaturzeitung 77 (1972): 715-720. H. Diem finds it impossible to distinguish between the activity and content of preaching. See Diem, Dogmatics, trans. H. Knight (Philadelphia: The Westminster Press, 1959), p. 164. Jeremias does not see preaching "as a kind of outer ring around the kerygma." See Jeremias, The Sermon on the Mount, trans. N. Perrin (London: Oxford University Press, 1961), p. 21.

${ }^{4}$ Matt $4: 23 ; 9: 35 ; 11: 1$; Acts $28: 31$; Rom $2: 21$. 
In summary, viewing the biblical material, listening to Worley's and other scholars' criticisms of Dodd, it can be maintained that it is not necessary to make such a sharp distinction between preaching and teaching. This implies that the followers of Christ, whether they proclaim or teach the gospel, are working with the same content and with the express purpose of making disciples of Christ.

\section{The Values of Biblical Preaching}

The values of biblical preaching are varied and can be seen in relation to the preacher and the listener. First, the preacher has the privilege of grappling with the biblical material. In other words, the preacher has what is needed and is saved from the frustrations of wondering where to find a message. Spurgeon writes:

There are hundreds of texts in the Bible which remain like virgin sermonets whereon the foot of the preacher has never stood. After thirty-five years. I find that quarry of Holy Scripture is inexhaustive. I seem hardly to have begun to labor in i.t.

If biblical preaching is proclaiming the saving acts of God in Christ, then the preacher has great scope for preaching, and this gives authority. Biblical preaching makes the preacher an expert in his field; it challenges him to his best intellectual and spiritual efforts, it gives him the deepest possible satisfaction, even though, at the same time, he wishes he would have done better; biblical preaching sends the preacher to the richest and most voluminous of all literature--the commentaries and works upon the Bible; biblical

$1_{R}$. Day, The Shadow of the Broad Brim (Philadelphia: The Judson Press, 1954), pp. 137-138. 
preaching offers opportunity for permanent contributions to human life. The top-ranking biblical preachers of all ages are still quoted, read, and revered (e.g. Matthew Henry, Adam Clarke, Joseph Parker, Alexander Maclaren, F. B. Meyer, B. H. Carroll, G. Campbe11 Morgan). ${ }^{1}$

Second, not only is biblical preaching a blessing to the preacher, but there are distinct values in this kind of preaching for the listeners. Many are biblical illiterates, and one way to help solve the problem is through biblical preaching. Miller says:

Preaching from the Bible serves the dual purpose of instructing the people in the Scriptures through the very art of preaching and stimulating their own inquiry into the Bible as well... The Bible in the pulpit is both the safeguard against error and the granary of spiritual food for the souls of one's people. 1

\section{Conclusions}

In an attempt to understand biblical preaching, one must view preaching as a dynamic process in which the preacher has the express purpose of proclaiming Christ to the contemporary mind. Christ crucified, risen, exalted; Christ in his mediatorial work in the heavenly sanctuary, and Christ's soon coming is recognized by the preacher as his message which is rooted in the Bible.

The preacher is not at liberty to preach his own ideas. Under the guidance of the Holy Spirit the preacher interprets, exposes, and proclaims the Christ-event in the light of the human situation.

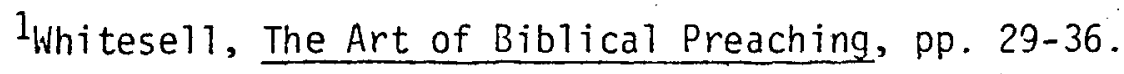

2mi1ler, pp. 105, 108. 
Biblical preaching will always remain one of the main tasks of the Christian church since it is one of God's chief means of making Himself known to the church and the world. If preaching is to stay alive, the preacher may have to take several facts seriousiy. Biblical preaching in relation to $i$ ts meaning is the interpretation and the proclamation of the Good News under the Spirit's guidance to the contemporary mind. The source of biblical preaching is the Christ-event and as such it has relevance for both preacher and congregation.

The importance of biblical preaching cannot be over-estimated. Apostolic preaching was biblical, post-apostolic preaching was biblical, Reformation preaching was biblical, Puritan preaching was biblical, and Wesleyan revival preaching was biblical. At every high peak of Christianity the preaching was largety biblical. 1

With this understanding of biblical preaching which has been developed in this paper as background, this study will now seek to discover various ways of applying this understanding of biblical preaching to the Jamaican situation.

Whitese11, p. 29 . 
PART II

THE CONTEXTUALIZATION OF AN UNDERSTANDING

OF BIBLICAL PREACHING INTO THE JAMAICAN SITUATION 


\section{AN OVERVIEW OF THE AFRO-JAMAICAN}

RELIGIOUS BACKGROUND

\section{The Roots of Jamaican Religious Heritage}

Contemporary Jamaica is a multi-racial society with the majority of its people being of African origin.' Its religious heritage is complex and diverse. Evidence of the process of syncretism² and retention of African elements in this present culture is observable in the social organization, language, religion, folklore, and music of the people.

The first Christians to arrive in Jamaica were the Roman Catholics who came with the Spaniards in 1494. Later, in 1662, the Church of England was established. Neither the Catholics nor the Anglicans took much interest in converting the slaves. This work was left for the Moravians who came in 1754 to Jamaica. They, in turn, were quickly followed by the Baptists and the Methodists with the

$1_{\text {At }}$ the end of 1973 the Jamaican population was as follows: African-- 76.3 percent, Afro-European--15 percent, European--0.8 percent, Chinese and Afro-Chinese--1.2 percent, East Indian and AfroEast Indian--3.4 percent, and others--3.2 percent. See General Facts on Jamaica (Kingston, Jamaica: The Agency for Public Information, 1975), p. 1 .

${ }^{2}$ Syncretism between the Western Christian and African ceremony and theology is most evident in the revival cults which fall chiefly into three groups known as Revival, Zionist, and Pocomania. See Joseph G. Moore, "Religious Syncretism in Jamaica," Practical Anthropology, (Tarrytown, New York: Practical Anthropology, 1965), 12:71. Another cult in Jamaica that we will examine later is the Rastafarians. 
Presbyterians and Congregationalists coming at a later time. ${ }^{1}$

Of special interest is the native Baptist church in Jamaica.

This particular church was founded by George Liele (1750-1823), a freed Negro slave who gathered the first Negro church in America at Silver Bluff in Georgia and became the first Negro Baptist minister in America. Mr. Henry Sharp, George Liele's master, recognized his ministerial gifts and encouraged him by granting him his freedom. Mr. Sharp, an officer in the Civil War, died from wounds received in service. Soon after his death there was contention over Liele's liberation. Liele was thrown into prison until he could produce his manumission papers.

To extricate himself from this unpleasant situation Liele (referred to as Negro Slave, prophet of deliverance) became indebted to a Colonel Kerkland. At the evacuation of Savannah by the British, George Liele was obligated to go to Jamaica as an indentured servant for money he owed Colonel Kerkland. ${ }^{2}$ After some time in Jamaica, Liele began to work with the slaves. A man without formal education, he learned to read the Bible and became a preacher of such effectiveness that in seven years he had converted five hundred slaves to Christianity. ${ }^{3}$

$1_{A}$. E. Sutton, Jamaica: Is land of Miracles (Nashville: Southern Publishing Association, 1966), p. 14.

2J. W. Davis, "George Liele and Andrew Bryan, Pioneer Negro Baptist Preachers," Journal of Negro History, vol. 3 (The Association for the Study of Negro Life and History, 1918), pp. 120-121.

$3_{E}$. A. Holmes, Foundations. A Baptist Journal of History and Theology 9 (Rochester, New York: American Baptist Historical Society, January-March 1966), pp. 337, 344. George Liele formed a church with 
The influence of George Liele cannot be overestimated. He touched the lives of some of the greatest religious leaders in Jamaica in the past: Moses Baker, who was baptized by Liele; William Knibb (1803-1845), 1 an English missionary to Jamaica whose prophetic voice was raised against slavery; Thomas Burche11, who worked closely with William Knibb; and James Mursell Phillippo, ${ }^{2}$ who led out in the religio-educational life of Jamaica (e.g., Calabar College).

Up to this point we have been looking at the entrance and development of missions in Jamaica. In relation to a religious syncretism, West Africa has played a major role in influencing the religio-cultural life in Jamaica as seen in its people, language, lore, and religion. We will look at these briefly.

The People

Although various tribes entered Jamaica, the most dominant

four brethren from America, including his wife and George Gibbs, who became a preacher at St. Thomas, St. Mary, and the Vale." Ibid., p. 337. "Ten years before the Baptist Missionary Society of England was formed and William Carey went to India, and thirty-two years before the American Baptist Missionary Union, which sent Judson to Burma, was organized, this Negro missionary launched his campaign." See An Hundredfold (Kingston, Jamaica: The Jamaica Baptist Union, 1949), p. 10 .

${ }^{1}$ For a detailed study of William Knibb's work in Jamaica, see P. Wright, Knibb "the Notorious" Slaves' Missionary 1803-1845 (London: Sidgwick and Jackson, 1973).

20n James Mursell Phillippo's involvement in education in Jamaica, see Gordon A. Catherial, "Freedom with Involvement," Foundation--A Baptist Journal of History and Theology 9 (Rochester, New York: American Baptist Historical Society, January-larch 1968), pp. 342-361; E. B. Underhi11, Life of James Mursel1 Phil1ippo, Missionary in Kingston, Jamaica (London: Yates and Alexander, 1881), pp. 311-312, 314; J. M. Phillippo; Jamaica: Its Past and Present State (London: John Snow, 1843). Liele's influence on the lives of Kinibb, Baker, 
were the Kramanti or "coromantyn"--the Ashanti-Fanti peoples of Ghana, followed by the Yoruba-lbo peoples of the Niger delta. The AshantiFanti culture complex dominated Jamaica as a whole. Most of the names of Maroon ${ }^{1}$ chiefs and generals that have come down to us were either Ashanti or Fanti in origin. Thus we have names like Cudgoe, Quao, Nana Acheampong, Kwaku, and Takyi. ${ }^{2}$

The Language

The official language of Jamaica is English--the language of the schools, the mass media, commerce, and technology. But the lingua franca of the Jamaican people is a Jamaican dialect called "patois," a mixture of English, Spanish, and various African languages.

Frederick Casidy in his book Jamaican Talk highlighted the strong African influence upon the Jamaican dialect when he wrote:

of non-Biblical influences it is obvious that the African is the largest and most profound; it appears not only in the vocabulary, but has powerfully affected both pronunciation and grammar. We may feel fairly certain of about two hundred and thirty loan-words from various African languages; and if the numerous compounds and derivatives were added, and the large number of untraced terms which are at least quasiAfrican in form, the total would easily be more than four hundred. Even at $i$ ts most restricted, the African element in the vocabulary is larger than all other non-English ones together. 3

Burchell, and Phillippo is evidence in his own dedication to his work and his presenting the magnitude of the task of working for the slaves.

1 The Maroons are an enclave composed of descendants of fugitive slaves who enjoyed freedom and local self-government. See M. G. Smith, The Plural Society in the British West Indies (Berkley and Los Angles: University of California Press, 1965), p. 97.

2L. E. Barrett, The Sun and the Drum (Kingston, Jamaica: Sangster's Book Stores, 1976), p. 16. See P. D. Curtin, Two Jamaicans (Westport, Connecticut: Greenwood Press, Publishers, 1968), p. 24.

3Jamaican Talk: Three Hundred Years of English Language in 
The Folklore

We will look now at Jamaican lore: which has significance for the proclamation of the gospel. Jamaican lore includes proverbs, saying, signs and omens, but we will focus only on proverbs. Proverbs are short sayings in common use that memorably express some obvious truths or familiar experiences characterized by terseness, rhythm, and striking imagery. They are probably the most useful linguistic device in any language to warn, to encourage, and to trigger reflection. In traditional Africa, proverbs were used not only as didactic tools but also in legal procedures and general debate. The more appropriately striking the imagery, the better the proverb. ${ }^{1}$

Jamaica (London: Macmillan, 1961), p. 394. Here are some examples of African words in Jamaica: one of the most commonily used words in Shrewsbury, St. Elizabeth is ono. This word is the third person singular of the Twi language of Ghana and is conjugated: me--I; wo--thou; one--he, she, it. See Immanuel Bellon, Twi Lessons for Beginners (Accra, London: Longman, Green, 1963), p. 4; quoted by Barrett, pp. 18, 19. Other expressions are buffu-buffy, a corruption of the Twi word for bofoo meaning clumsy, swollen, fleshy; a person who is disorderly in appearance is referred to as chaka-chaka; one who has not done a good job is said to nyaka-nyaka his or her work; in Accra, the word fenky-fenky has reference to a person who is fastidious in appearance.

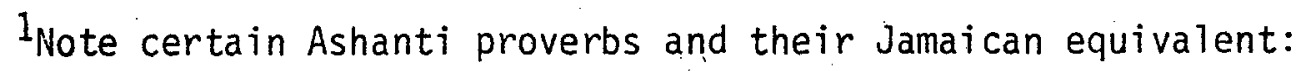

\section{Ashanti}

A sheep does not give birth to a goat.

Path has ears.

When a fowl drinks water, it (first) takes it and shows it to the Supreme Being.
Jamaican

Sheep and goat no all one.

Bush has eyes.

When fowl drink water, him say

"tank God."

The Ashanti proverbs and their Jamaican equivalencies are given in the words of Barrett, pp. 35-37. For further study of Jamaican and Ashanti proverbs, see R. S. Rattery, Ashanti Proverbs (London: Oxford University Press, 1923). On Jamaican proverbs see F. Condall, Jamaica Negro Proverb and Sayings (Dingston, Jamaica: 1910). 
Earlier mention was made of the religious syncretism in Jamaica which is evident in three revival groups: Revival, Zionist, and Pukumina. ${ }^{1}$ Like most Protestant bodies in Jamaica, these groups make use of hymns, sacred songs, and portions of the Bible. However, the most Jamaican of the cults that has African ties is the Rastafarian movement. ${ }^{2}$

The Rastafarian movement began to take shape about 1930. The decade beginning in 1930 may well be called the "decade of despair" for the average Jamaican. The political situation was stagnant. The average wage for a full day of unskilled labor was twenty-five cents for men and fourteen cents for women. These were years of violent

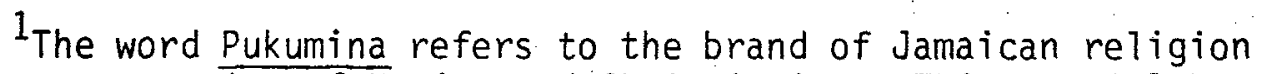
which is a syncretism of Kumina and Christianity. This special brand of Jamaican religion is believed to have emerged out of the 1860 revival which swept the island a generation after the emancipation of the slaves. The name of this religion in Jamaica is Pocomania, and as the word suggests, the rights of the religion, with its dance, trumpling, and possession. See Barrett, p. 27; J. G. Moore, "Religious Syncretism in Jamaica," Practical Anthropology 12 (New York: Practical Anthropology, 1965): 62-70.

2In 1976 it was estimated that there were about 70,000 Rastafarians in Jamaica. The books of Deuteronomy, Leviticus, Numbers, Isaiah, and Daniel figure greatly in the sources of Rastafarian doctrine. Some of their principal doctrines are as follows: the humanity of God and the divinity of man, historicity of the experience of God's workings, the supremacy of $1 \mathrm{ife}$, the efficacy of the Word, the imminence of judgment, the corporate dimensions of evil, the priesthood of Rasta, etc.

For further study of this movement see G. E. Simpson, Religious Cults of the Caribbean (Rio Piedras: Institute of Caribbean Studies, University of Puerto Rico, 1970), pp. 208-223; M. G. Smith, Roy Augier and Rex Nettleford, The Ras-Tafari Movement in Kingston, Jamaica (Mona, Kingston: Institute of Social and Economic Research, University College of the West Indies, 1962); Joseph Owens, Dread, the Rastafarians of Jamaica (Backerville: Montrose Printry, 1976); Idris Hamid, ed., Troubling of the Waters, San Fernando, Trinidad: Rahaman Printery, 1973), pp. 165-170. 
hurricanes: which left Jamaica and other West Indian islands devastated.

Feelings of despair and gloom came to a head in labor disturbances in 1938. This despair also gave rise to the first political parties in Jamaica and also indirectly occasioned the birth of the politicoreligious movement. ${ }^{1}$ From a religio-political and economic point of view, Simpson gives this summary description:

Ras Tafarism is a functional alternative, or functional equivalent, for orthodox and Revivalist religions, political parties, and other. social organizations in the economically depressed area known as West Kingston. Although members of this cult denounce ministers and their congregations, their own doctrine provides a deity (Haile Selassie), a heaven (Ethiopia), a sacred book, (the Bible), a devil (the white man), sins and punishment (exile to the West Indies), a prayer, and numerous hymns. Ras Tafarism will grow or decline as the economic and social conditions of lower-class Jamaicans change and as its functional alternatives increase or decrease in appeal. It is one index of the integration, or lack of integration, of Jamaican society. 2

This group places strong emphasis on the Bible which should provide points of contact for preaching. More than this, these people are a part of the Jamaican society and, therefore, the church needs to address itself to their situation.

\section{Present Religious and Political Mood of Jamaica}

The present religious and political mood in Jamaica must also be considered. It should be remembered that Jamaica has experienced a continuity of religious experience; in other words, there has not

$1_{L}$. E. Barrett, Soul-Force: African Heritage in Afro-American Religion (New York: Anchor Press, 1974), pp. 157-158.

2G. E. Simpson, Religious Cults of the Caribbean: Trinidad, Jamaica, and Haiti (Puerto Rico: University of Puerto Rico, 1965), p. 223. 
been a break in the historical Protestant groups from the present. This is true of the various cults. Another important fact that needs to be stated is that cults which were viewed with disrepute have now achieved respectability. Various studies ${ }^{1}$ that have been made with regards to religious groups have influenced such attitudes, as has also the fact that these groups are seen as a viable part of the Jamaican society. This is clearly an aspect of the Afro-Janiaican experience. Therefore, the church cannot turn its back upon this religious phenomenon. Rather, its proclamation must be addressed to it.

Another aspect of the present religious experience of Jamaica is escapism and a desire to have an authentic, indigenous theology. This indigenous theology motif is also true of the entire Caribbean area. On the concept of escapism Stone writes on Jamaica:

Since national independence, religion in the island has generally buttressed conservatism. It has also fostered escapism. The Anglicans have longed for England, the Pentecostal have yearned for shoes in heaven while walking bare foot on earth, and the Rastafarians, the most Jamaican of the group, have dreamed of an Exodus to Ethiopia.?

One of the things that may have fostered this spirit of escapism and conservatism is the radical nature of the political system with which, in many cases, the populace cannot cope.

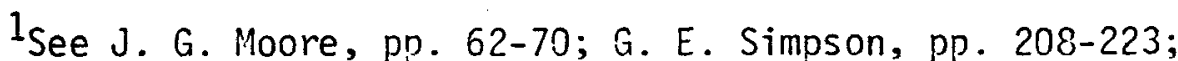
J. Owens, Dread, the Rastafarians of Jamaica; L. Barrett, The Rastafarians, Sounds of Cultural Dissonance (Boston: Beacon Press, 1977); Barrett, Soul-Force: African Heritage in Afro-American Religion.

${ }^{2}$ Ronald Stone, "A Black-Liberation Theology from Jamaica," The Christian Century 91 (The Christian Century Foundation, JulyDecember, 1974): 750 . 
A relevant theology seems necessary to help reinterpret the black aspect of the Jamaican flag. ${ }^{1}$ The country has been influenced by two theological streams of thought: black theology from North America and Tiberation theology from Latin America. The reception of black theology has created a kind of ambiguity in that there are some Jamaicans who want to be English, while the majority would like to discover the strength and dignity of being black. An indiginous black theology which is rooted in the doctrine of creation and redemption is relevant to the blackness of the Jamaican people.

Many Caribbean theologians are seriously reflecting on the development of a Caribbean theology that must emerge out of the religious experience of the people. ${ }^{2}$ In the book, Troubling of the Waters, edited by Idris Hamid, there are some articles such as, "The

In the Jamaican flag, the gold is for the light of the sun, the green for the beauty of the nation, and the black reflects the hardships of the people. I am suggesting that the black may reflect the strength, beauty, and dignity of the people.

${ }^{2}$ The Jamaican church can adopt several theological postures: (1) It can adopt a "theology of absorption." This was true of the church which through the work of its more sophisticated converts absorbed the atmosphere, the hierarchy, and many of the cosmic presuppositions of the Greek and Roman world and approached the relationship between man and God with this technique of absorption. (2) It can accept a "theology of imposition." At the beginning of the second great age of Christian expansion Christianity was the religion of Europe. (3) The reaction of colonials to a theology of imposition was the "theology of imitation." This is another posture the Jamaican church can take. (4) I am suggesting that the most viable options for the Caribbean church and in particular the Jamajcan church is a "theology of exploration." In order to discover the relationship between God and Caribbean man, it is necessary for Caribbean man to do more exploration of himself, his environment and the forces which have given that environment their peculiar structure. See Moore, "The Historical Basis of Theological Reflection," Troubling of the Waters, pp. $37-45$. 
Challenge of Theological Reflection in the Caribbean Today, "1 and "The De-Colonization of Theology." 2 The Caribbean preachers, and particularly the Jamaican preachers must take cognizance of this changing theological climate; in other words, it makes sense to preach to the times.

The second consideration is Jamaica's politics. Earlier it was established that the proclamation needs to be related to the culture, and since the political system is a part of culture this aspect is in order.

At present, the Jamaican people have been thrown into a state of uncertainty. They have lost confidence in the political system and many believe that the economic problems that exist in Jamaica are to be blamed on the government. To put it bluntly, the populace of Jamaica is wondering in which direction "democratic socialism" will take the country. Politically, Jamaican people are feeling a sense of hopelessness.

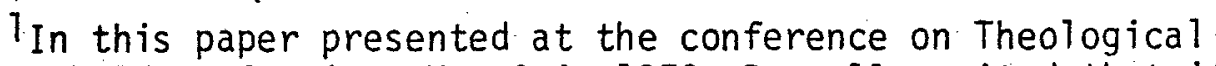
Reflection held in Jamaica, May 3-4, 1973, Russell posited that it has become increasingly clear that old truths need to be re-defined and stated with clarity. New truths need to be recognized. This appraach does not deny the "givenness" of the Christian faith, nor rejects its unique quality..." See Russell, "The Challenge of Theological Reflection in the Caribbean Today, "Troubling of the Waters, pp. 25-34.

In this article, Watty attempts to de-emphasize theology's meta-physical bases and to stress the social-scientific and biblicalhistorical foundations. Thus he tries to authenticate an eschatology which will provide "a sober and realistic understanding of the island's destiny." He sees a nation's values and its spiritual contribution to the life of humankind as the marks of greatness. Israel and not Babylon, he says, is the beacon by which Jamaica should steer. W. Watty, "The De-Colonization of Theology," Troubling of the Waters, pp. $49-80$. 
In sum, Jamaica is complex ethnically and it is multi-racial. The religion has a great degree of syncretism, with the dominant influence being African. With respect to its present religious and political: life, there appears to be a religious continuity between its past and present religious experience; politically, however, there is a state of uncertainty.

This is the kind of Jamaicainto which an understanding of biblical preaching must be addressed. How then sha11 we communicate the gospel in the Jamaican milieu? 


\section{COMMUNICATING THE GOSPEL IN THE}

JAMAICAN CONTEXT

No man can effectively proclaim the gospel unless he devotes constant study to the culture and audience ${ }^{1}$ he hopes to engage with the gospel. He must take a hard look at the meanings and attitudes already established in that culture. As will be shown, even the biblical material of the $01 \mathrm{~d}$ and New Testaments, while it is not an assimilation of societal values, reflected certain aspects of the cultural milieu. So it has ever been the task of the preacher to understand the mind he addresses and to find appropriate words and symbols to express God's mind. The preacher will want to ask such questions as: How do people think in this particular culture? What are the values of people? What issues are crucial? Do people tend to be more rational than emotional? In short, how can the Christian message aim at and hit with a calculated accuracy the complex target of minds? In addressing these questions, preaching as biblical storytelling will be examined as a point of departure.

$1_{\text {This means that the preacher needs to know the different }}$ types of audiences that he addresses. The Bible recognizes at least four types of audiences (Matt 13:4-8, 18-23). Perry discusses four types of audiences in terms of interests and their attitudes toward the speaker and his ideas: the apathetic, the believing, the doubtfur, and the hostile audiences. See L. M. Perry, Biblical Sermon Guide (Grand Rapids: Baker Book House, 1970), pp. 113-120. These various types of audiences are also present in Jamaica. However, one of the outstanding things about the Jamaican audiences is that the religious roots go deep in its culture. This makes it easier for the gospel to be presented. 


\section{Preaching as Biblical Storytelling}

The importance of preaching as biblical storytelling cannot be overestimated. Most people think in pictures, and the Jamaican audience is no exception. The idea of the dramatic in Jamaica has its roots in Africa, which in turn is closely related to the biblical mode 1 .

Israel lived by stories. What had to be said about God and the meaning of life was passed from father to son: the story of the Garden of Eden, the remembered patriarchs and their enslaved sons in Egypt; the great epic of the Exodus and the bold sagas of the new land and Israel's brave leaders. The greatest of Israel's preachers relied upon drama to convey meaning; Jeremiah wore a yoke of iron and smashed dishes in the streets of a threatened Jerusalem. Ezekiel, the exile, lay seige to his own house and cut his hair as one already captured. Amos used a carpenter's tools to speak of justice and offered a basket of summer fruits to decaying Samaria. Word and event were one in Israel's faith. In short, history and everyday things, the stuff of story, were the vehicles of revelation as they were life itself. 1

Like the biblical tradition, the centrality of the oral process is basic for the transmission and the preservation of religious and cultural values. Mitchell comments that "the oral processes, long

${ }^{1}$ C. L. Rice, Interpretation and Imagination (Philadelphia:

Fortress Press, 1970), p. 66 . 
lost in most Western societies because of the advent of the printing press, have survived amazingly well in such places as West Africa."1 The Jamaican populace received their concept of folk story from Africa .

The whole concept of the "once upon a time" motif in Jamaica holds great implications for the preacher's style of delivery. Sleeth believes that the major task of the preacher is to make the essentials of the Christian faith come alive to his people. ${ }^{2}$ It means that the preacher must acquire the art of storytelling, of presenting the gospe 1 in such a dramatic form that he and the congregation participate together. The sermon becomes a shared experience in which the gospel unfolds before the eyes. Whether the preacher is dealing with the biblical material as story or using a story to illuminate the gospel, there must be dynamic movement in the sermon. In other words, the sermon must begin, move, and stop. 3

If the preacher is descriptive and dramatic enough, the listeners can say, "That's. me, that's my story." Even when the preacher deals with complicated material that demands elaborate exegesis and profound exposition, he will want to dramatize the message. The biblical preacher then will narrate and illustrate the biblical truth.

1H. H. Mitche11, The Recovery of Preaching (New York: Harper and Row, Publishers, 1977), p. 75.

${ }^{2} R$. E. Sleeth, Persuasive Preaching (New York: Harper and Brothers, Publishers, 1956), p. 66 .

3 For a more detailed study of preaching as storytelling, see M. Crum, Manual on Preaching (Valley Forge: Judson Press, 1977), pp. 15-45, 97-109. On the art of storytelling, see G. A. Fessenden and others. Speech for the Creative Teacher (Iowa: William C. Brown Company Publisher, 1973), pp. 217-221. 
For some practical ways in which the preacher can become effective in the art of storytelling, Fessenden and others make the following suggestions to the preacher.

1. He should familiarize himself thoroughly with the story or, if the story is a personal experience, rehearse it in his mind until all details are clear and in sequence.

2. If the story needs to be adapted, he should make his cuttings with great care.

3. He should study the characters in his story, distinguish carefully between the major and minor characters in the story.

4. He should stick to the plot. There should be a developing sequence of events.

5. He should avoid memorizing the story, although there may be certain sentences or particular bits of conversation that he will want to use word for word because of the special "flavor" they give.

6. He should practice telling the story aloud. Rehearsal should take place several times.

7. Finally, "he should put himself in the story with zest" and with enthusiasm. 1

Experts on storytelling have given the following guidelines:

1. Tell the story as naturaliy as possible.

2. Make every sentence as fully expressive as possible. The little word "oh!" for example, can say, "I'm glad," "I'm sorry," "I don 't believe it," "I'm shocked," "How could you!" and it can express many other feelings or reactions.

1 Ibid., pp. 217-218. 
3. Forget yourself and think of your story. This is also a good antidote for self-consciousness.

4. Keep in mind that your story is for your audience.

5. Talk directly to your audience and develop a pleasing voice quality.

6. Stop when you are through. ${ }^{1}$

Not only should the preacher make the biblical story come alive by the way he delivers the sermon, but it is his duty to make relevant the biblical story. The biblical tradition should be interpreted and applied to the Jamaican situation.

\section{Preaching and Folkculture}

In communicating the gospel, the preacher will want to draw upon the existing culture in which he operates. For example, the Bible does not remain completely untouched by mythological tendencies from the ancient Near East. ${ }^{2}$ Not only do we find the 01d Testament making use of existing belief in their culture, but this is also true of the New Testament. Paur quoted from great poets in the book of

Ibid., pp. 218-220.

${ }^{2}$ The concept of the sun as winged (Mal 4:2) was familiar from Egyptian usage. References to demonic figures such as Lilith (Isa 34: 14) and Resheph (Hab 3:5; Job 5:7) reflect Canaanite folklore in an analogous manner. Allusions to epics of ancient deities have been seen in hints found in various parts of the 0ld Testament relating to a primordial revolt in heaven (Ps 82:6; Isa $14: 12 \mathrm{ff}$ ), or references to astral bodies (Job 38:31f; Amos 5:26). A more direct parallel to pagan mythological ideas has been envisaged in the scattered references to divine conflict with some kind of monster, variously named Leviathan (Job $3: 8$; Ps $74: 14$; Isa 27:1), Rahab (Job $9: 13$; 26:12f; Ps 89:10; Isa 30:7; 51:9f), Tannin, i.e. "Dragon" (Job 7:12; Ps 74:13; Isa 27:1; 51:9), Yam, i.e.,"Sea" (Job 7:12; Ps $74: 13$; Isa $51: 10$; Hab 3:8), and Nahan, i.e.,"River" (Ps 93:3; Hab 3:8). See R. K. Harrison, p. 457. 
Acts. ${ }^{1}$ Many of the biblical references to other sources in this culture were used for two main purposes: to assert the absolute power of God and therefore the ridiculing of pagan deities, as in the case of the 0ld Testament, and also as a point of contact, thus teaching truth about God as in the case of Paul.

If we look at the second-century Christians, we can gain insights as to how they approach outsiders with the gospel. Richardson points out how often Christian artists employed pagan myth and forms in their attempts to convey distinctly Christian motifs. ${ }^{2}$ Richardson goes on to talk of the artistic phenomena in the Roman catacombs, "The fish which swallowed Jonah is the dragon of Andromeda, and Jonah reclining beneath his gourd is Endymion. 'We even find Christ directly pictured as Orpheus charming wild beasts, ' a collection of pagan symbols intended to convey the substance of Isa $11: 1-6.13$

Two Christian apologists who made use of pagan symbolism as a

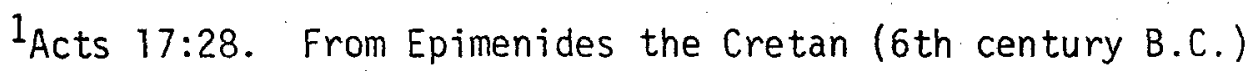

Paul quoted from the following poem:

They fashioned a tomb for thee, 0 holy and high one--

The Cretans, always liars, evil beasts, idle bellies!

But thou art not dead; thou livest, and abidest forever;

For in thee we live and move and have our being (Emphasis mine.)

Paul also quoted from poet Aratus from Ci Ticia (Paul's own hometown)

From Zeus let us begin; him do we mortals never leave

Unnamed; full of Zeus and all the streets and

All the market-place of men; full is the sea and the heavens thereof; always we all have need of Zeus

For we are also his offspring. (Emphasis mine.) See NichoT, Seventh-day Adventist Bibie Commentary, voi. 6, pp. 353,354.

${ }^{2}$ See C. C. Richardson, "The Foundations of Christian Symbols," in Religious Symbolism, ed. F. E. Johnson (New York: Institute of Religious and Social Studies, 1955).

${ }^{3}$ See J. E. Sellers, The Outsider and the Word of God: A Study in Christian Communication (Nashville: Abingdon Press, 1961), p. 61. 
point of contact or conflict were Justin Martyr and Tertullian. Justin, who was against Greek philosophy, made it a point of conflict. Tertullian made it a point of contact in order to convey the Christian message. To be more specific, Tertullian turned to Roman governmental theories for his symbols. 1 This principle can be applied in the Jamaican situation.

The hero of the Jamaican folklore is the Ashanti, Anansi Krokroko, the spider. He is closely identified with the name Tacooma, the symbol of wisdom and trickery. Anansi supposedly expresses a complex attitude: there is his ostentatious professions of love; his wrong and strong cowardly posture of bluff; his love for leisure and corresponding dislike for work, and his lovable rascality. ${ }^{2}$ During the slave days, Anansi (Spider) had special significance to the slave who, in identifying with Spiderman hero, could turn the tables, so to speak, on the white oppressor. ${ }^{3}$ The Jamaican preacher can use Anansi and his cohorts and, at times, adversaries (including

1Tertullian declares: "Monarchy, because it is the rule of one, does not preclude the monarch, who enjoys that rule, from having a son. . it does not cease to be a monarchy, if the son also is brought in as a partner in it." Here Tertullian is laying a foundation for the doctrine of the Trinity. This Father-Son partnership goes over into another governmental term, persona, which speaks of a man's personal rights and duties. See Against Praxeas 3. (ANF, 3: 597-632.

2Walter Jeky 11, Jamaican Song and Story (New York: Dover Publications, 1966), p. viii.

${ }^{3}$ Barrett, p. 34. For more on Jamaican folklore see joseph $\mathrm{J}$. Williams, Psychic Phenomena of Jamaica (New York: The Dial Press, (1934); Martha Beckivith, Black Roadways: A Study of Jamaica Folk Life (Chapel Hi11, N.C.: University of North Carolina Press, 1925); Madeline Kerr, Personality and Conflict in Jamaica (London: Liverpool University Press, 1963. 
his wife, Crooky, Goat, Kissander the cat, Pea fowl, and Tiger, among others) to teach truths or to be prophetic as he (the preacher) speaks out against the evils of the Jamaican society.

Then the Jamaican preacher can make use of traditional wisdom and maxims. For example, there is an African saying that there are three things worth having in this world: courage, good sense, and caution. ${ }^{1}$ As in Africa, so in Jamaica: the proverbs are not merely told as stories, but are a living part of the folk tradition and the vehicles of conversation. ${ }^{2}$

It would be a mistake to assume that one's hearers in Jamaica have no knowledge of Deity or that he is addressing irreligious people. Apart from the fact that Jamaica is a Christian society, it must be recognized that because of the Jamaican roots in African religious tradition, religion occupies the entire life of a person. Therefore, to be without religion amounts to a self-excommunication from the entire life of society. ${ }^{3}$ Unless the Christian religion can occupy the whole person as much as, if not more than, traditional religions and cults, then new converts will return to their former

$1_{\text {Ibid., p. } 37 .}$

20n courage, a fitting Jamaican proverb is: "No call a man dead till you bury him"; a proverb that teaches consistency, steadyness of purpose, and perseverance toward a goal in $1 \mathrm{ife}$ is: "When you find a safe road follow it a long time"; on generosity and the value of sharing: "If you share what you have, you will receive more than you need." See Barrett, p. 38. On the concepts of signs and omens, healing and medicine, witchcraft and psychic phenomena in Jamaica, see Barrett, pp. 39-110.

3 John S. Mbiti, African Religions and Philosophy (New York: Anchor Books, Doubleday and Company, 1970), p. 3. 
beliefs. Knowing this, the preacher and the church in general will make sure that each aspect of the people's cultural life is engaged by the gospel.

Preachers can easily adopt a negative attitude toward the different sects in Jamaica. For example, Davis believes that the sects in Jamaica present a threat to the Jamaican "established churches." He holds that "the presence of many irresponsible and emotional religious groups in the island is one of the most baffling problems of the church." 1 However, it is my view that Davis's statement is highly irresponsible. The duty of the church is to understand people where they are and not to make emotional and unsubstantiated statements about them.

What we have been saying so far is that in communicating the gospel in the Jamaican culture, the preacher is wise if he draws from the cultural heritage of the population so that there can be a point of contact. Preaching that makes meaningful impact on lives has to reach persons at a depth, and it is at this level of communally stored wisdom and cultural affinity that such access to living souls is gained. 2

At the same time the preacher's theology must be brought to bear upon cultural values. He is not to be shaped by society. Rather the preacher and the culture of which he is a part stand under the

1J. M. Davis, The Church in the New Jamaica (New York: The Academy Press, 1942), p. 41 .

2 Mitche11, p. 29. 
lordship of Christ. ${ }^{1}$ Christ is the converter of culture.

In communicating the Good News within the context of the Jamaican situation, the preacher will bear in mind that the culture on a whole is an expressive one, a culture that expresses itself in folksong, literature, cult-life, and various other forms. So then, in their context, preaching and celebration cannot be separated.

\section{Biblical Preaching and Celebration}

A part of the genius of black, preaching is the capacity to recapture and generate the spirit of celebration, even in the hardest of times. This is not unique to the black culture. The Hebrew religion was celebrative in many of $i$ ts yearly feasts. In the African setting, most of the folk gatherings were around the happy themes of birth, marriage, planting, harvest, and the advancement of the young as they pass through different stages of life. Even the grimness

$1_{A}$ many-sided debate has been waged over the relationship that exists between Christ and culture. Niebuhr has given at least five models: (1) the opposition between Christ and culture (In this camp Tertullian has stated this in radical fashion--the best loved books of the time, such as The Teaching of the Twelve, The Shepherd of Hermans, The Epistle of Barnabas, and the First Epistle of Clement-present Christianity as a way of life qui te separate from culture); (2) the fundamental agreement between Christ and culture--the typical answer offered by a second group; (3) Christ as the fulfillment of culture--held by some people; (4) the duality and inescapable authority of both Christ and culture--also recognized, al though the opposition between both is accepted; and (5) the conversionist solution which is close to the first and fourth groups--human nature is fallen or perverted, and this perversion not only appears in culutre but is transmitted by it. Christ is seen as the converter of man in his culture and society. Augustine and Calvin are associated with this position. While there is a modicum of truth in the first four models, I believe that the fifth model is closer to the Christian position. See H. R. Neibuhr, Christ and Culture (New York: Harper and Row, Publishers, 1951). 
of death was not without joy. Jamaica falls within this tradition of expressiveness and joy.

Celebration, which is simply to make public our faith, 1 has several functions within the Jamaican culture. Some of these may be applicable to other cultures. First, because of its historical background with regards to oppression, both past and present, celebration served to create a habitual "living space," and, as Mitchell puts it: "The establishment of a celebrative island of consciousness in an ocean of oppression and deprivation." 2 Jamaicans were not particularly submissive to their masters (the many rebellions in Jamaica prove the point) and there were hard times in the past. The present also poses difficulties for the Jamaican people in terms of economic problems. However, celebration can serve as a buffer.

A second function of celebration is its confirmation of the quality of the gospel to recognize personhood. The gospel pulls this joy out of a person. Preaching is the sharing of the Good News and preaching without celebration is a denial of the gospel. In the black worship experience, the whole person is involved. The intellect cannot be separated from the emotions. The worshipers are free to express themselves. A supportive structure is provided in which persons are free to pour forth their feelings and to celebrate their own personhood in the midst of celebrating the goodness of God. ${ }^{3}$

Finally, after the preacher has done his work in exegesis,

1D. J. Randolph, God's Party (Nashville: Abingdon Press, 1975), p. 17.

2Mitchel1, p. 57.

$3_{\text {Ibid. , p. } 56 .}$ 
the exposition of Scripture and application by way of dramatic storytelling, celebration becomes a fitting climax. In the words of Mitchel1:

The best reinforcement and the greatest expression of joy must naturally occur when so to speak, the lesson is completed and summarized, and thanks and celebration are offered for it at the end. All else leads up to this climatic moment, and whatever follows is inevitably anticlimax. Like a symphony, the theme is stated majestically and powerfully, with prior elaborations now taken for granted. Fresh spiritual insight and illumination, joyous recall, and persons fulfilled in community are celebrated together. 1

One word of caution. Within recent times the word celebration has taken on a loose kind of meaning which borders on emotionalism. However, we are speaking about celebration which involves both the intellect and the emotion. In short, the whole person is taken into consideration.

Authentic preaching takes seriously the act of celebration, a celebration that expresses the joys of salvation. However, this kind of controlled and rational joy needs to find verbal expression within the context of worship. This can be expressed through dialogue.

\section{Biblical Preaching and Dialogue}

Communicative preaching is dialogical and always has been. It is characterized by the preacher's concern for the attitudes, experiences, and needs of his people. And as was pointed out before, biblical preaching takes seriously the "I-Thou" relationship. In dialogical preaching there is participation. Howe explains: "dialogue... is that interaction between persons in which one of them seeks to give

$$
1_{\text {Ib id., p. } 58 .}
$$


himself as he is to the other, and seeks also to know the other as the other is." I

While it is true that some Jamaicans have been influenced by the British conservative spirit, the majority of people in Jamaica are expressive. This is especially true in certain religious bodies. There is a warmth between preacher and people. It is not uncommon to hear shouts of "amen"2 and "hallalujah." This has implications for the preacher and the people. It suggests a closeness between pulpit and pew. An even wider theological implication is the concept of the priesthood of all believers. The preacher is part of his audience. The black preacher does not maintain a professional distance from his congregation. This would be contradictory to the biblical teaching of the kingdom of God, in which "there is neither Jew nor Greek, there is neither slave nor free, there is neither male nor female; for you are a 11 one in Christ Jesus." 3

Another implication that preaching as dialogue holds for the preaching situation is that audible response is a signal that people's needs are being met. This does not mean that there are not meaningless expressions; neither does it mean that the art of silence suggests that needs are not being met. However, worship is more participation and action than silence.

$1_{R}$. Howe, The Miracle of Dialogue (New York: The Seabury Press, 1963), p. 37. For information on dialogue preaching see: W. D. Thompson and G. C. Bennett, Dialogue Preaching (Valley Forge: The Judson Press, 1969):

${ }^{2}$ See Neh $8: 6 ; 1$ Chr 16:36; Ps 106:48; 41:13;89:52; 1 Cor 14:16; Rev 22:20. See also Ellen G. White, Testimonies to the Church, (California: Pacific Press Publishing Association, 1948), 3:318.

$3_{\text {Gal 3:28. }}$ 
The dialogue method in which there is meaningful interchange between preacher and people has been completely "road-tested" in Black culture, approved, and given permanent place. It includes responses from the pew which range al1 the way from brief bursts of affirmation (Amen! Yes sir. So true! Preach it brother! etc.) to congregational chant ("The Lord is My Shepherd, I Shall Not Want," "Lord, Have Mercy... on My Soul," or "Bread of Heaven, Bread of Heaven, Feed He till I Want No More.") The direct request or candid appeal for the audience's support in the preaching struggle may take a variety of forms: "Are you praying with me?" "You're getting mighty quiet out there." "Can I get an Amen?" or "Help me, Jesus!" At times the expression, "Mercy, Lord!" draws another "Mercy" from the audience.1

- Below is an example of what takes place between preacher and people in the Black church, especially in America:

"Every man is followin' God ...., callin' God's word. $\therefore$ Now don't you? LPauses. "That's all right." "Yeah!" etc. $\bar{I}$ How long? How long? $/ \overline{\bar{P}}$ auses. "Dat's all right!". etc. Tears up the plot of ground of your heart! Put you ter talkin' plain. . . Knocked Paul down between Jerusalem and Damascus when Paul was a servant of God!... No one knows the Son but... I"Everything's all right, Rev. Amos." etc. T It's a bad thing to bother with a child of God. . . And the wind hadn't blown. /In his stride again now. $\dot{\bar{j}}$ it thundered and no one hadn't heard! The lightening hadn't played a lengthy game across the murky cloud! Heaven hadn't been burned or hell even warmed up, or even organized. . . . L"Talk now!" "Ride it, Amos" etc. 2

Dialogue is important in the Jamaican audience in that

1Mitche11, pp. 117, 118.

2This is an exerpt from the sermon, "Elijah, the Man of God," W. H. Pipes, Say Amen, Brother! (Westport, Connecticut: Negro Universities Press, 1951), p. 43. 
it recaptures what Mitche11 calls "shared certainties" and "no certainty is more shared than the providence of God." 1 At the time of emancipation in 1838 there were $218,550^{2}$ land slaves in Jamaica. Michael Manley, Prime Minister of Jamaica, said of colonialism:

It was not the product of a conquest of our territory by foreign arms. It was not the super-imposition upon our social and economic fabric of an external mechanism of exploitation. Rather, colonialism was the condition within which we were born: it was literally the midwife of our early history. Our recorded Caribbean story begins with displacement: the white European settler on whose behalf the African slave was captured, and the indentured Indian worker purchased; settler, slave or servant--all were displaced. ${ }^{3}$

Today, after nearly one and a half century, Jamaica has emerged as an independent nation, though desperately working "towards a society that is egaliterian in structure, cooperative in motivation and self-reliant in psychology." 4

Looking back over the road over which Jamaica has travelled-from slavery to nationhood--is cause fior celebration, which can be expressed in worship. The individual Christian can do the same because of God's deliverance from the slavery of sin.

1Mitchel1, p. 130.

20. Hal1, Free Jamaica, 1838-1865, An Economic History (New Haven: Yale University Press, 1959), p. 157; R. Hill gives the number as 218,669. Lights and Shadows of Jamaican History (Kingston, 1859), o. 144 .

${ }^{3}$ Taken from a speech by M. Manley, Prime Minister of Jamaica, at the University of the West Indies, December 14, 1974, see Government Policies of Home and Abroad (Kingston, Jamaica: The Agency for Public Information, 1975), p. 3.

${ }^{4}$ Ibid., p. 5. 
It must not be forgotten that there is a risk involved in dialogue. It can get out of hand and the preacher can be manipulative in his use of dialogue. Dialogue demands discipline on the part of both preacher and congregation. The fear that the congregation will get out of hand can be controlled to a large extent by the preacher. He needs to respect his hearers and not see them in the light of his manipulative behavior. Ethics will play a large part in the preacher's persuasive methods. It is irresponsible to say, "I do not care what method I use as long as people respond to the gospel." The end does not justify the means. Paul's statement to the Thessalonians is very instructive when he writes:

For our appeal does not spring from error or uncleanness, nor is it made from guile; but just as we have been approved by God to be entrusted with the gospel, so we speak, not to please men, but to please God who tests our hearts. For we never use either words of flattery, as you know, or a cloak for greed, as God is witness. 1

Christian persuasion should take cognizance of the freedom of the human will, also of love and justice. Griffin ${ }^{2}$ writes of significant types of loves in relation to ethical/unethical persuasions. With ethical responsibility on the part of the preacher, dialogue can be controlled and thus be effective.

\section{${ }^{1} 1$ Thess $2: 3-5$.}

2(1) The non-lover: he does not try to persuade, his motto is, "Live and let live." (2) The flirt: the flirtatious lover is in love with himself and is status oriented. (3) The seducer sings "every day with Jesus is sweeter than the day before" without explanation. (4) The rapist uses cohersion. (5) The legalistic lover lacks love. (6) The true lover respects the right and dignity of the person. E. Griffin, The Mind Changers: The Art of Christian Persuasion (Illinois: Tyndale House Publishing, 1976), pp. 32-40. 
We have said that in proclamation dialogue is important in the Jamaican situation in that it creates warmth between pulpit and pew. Because of the Jamaicans' historical background, biblical preaching which is dialogical is relevant. Not only is there a nonprofessionalism between the people and preacher, but dialogue in the Jamaican milieu helps to reclaim "shared certainties."

In a discussion of communicating the gospel in the Jamaican society, it is important to take into consideration the existential societal needs of the people. This is crucial because the raison d'tre for preaching is for the sake of the hearers. To understand the needs of the hearers, the preacher needs to discover for himself the axioms that exist in the society.

Societal Values, the Existential Needs and the Role of Biblical Preaching

Two basic things will be discussed in this section of the paper: (1) a brief look at some soeictal values and (2) how these give rise to certain existential needs to which preaching must be addressed. Values can either be negative or positive and in two ways as a point of conflict to be challenged by the gospel or as a point of contact to be confirmed.

There are certain universal axioms ${ }^{1}$ of modern man that are

1Brunner has given the following axioms of the modern man: (1) everything is relative; (2) what can't be proved can't be believed; (3) scientific knowledge is certain and the standard of truth, matters of faith are uncertain; (4) beyond death nobody knows; (5) "real" means seen and handled; (6) the big things are the great things. Because man is so small in this big universe he is so little; (7) I cannot help being what I am; (8) freedom means doing what I like; (9) justice 
applicable anywhere. Many spring from the basic characteristics of man's selfish nature such as, only the tangible is real, no one is sure of tomorrow, everything is relative. These must be challenged by the gospet.

In turning to the societal values of Jamaica, we will attempt. a definition of values, a system that is an integral part of the culture. Nida defines culture as "all learned behavior which is socially acquired, that is, the material and nonmaterial traits which are passed on from one generation to another."1 By value we mean a concept that refers to certain ideas on which the society places premium. As the word implies, it refers to those ideas that are valued. 2 More directly we are concerned with the value systems that

means equality; (10) to put religion first is religious arrogance; (11) laws of nature determine everything. See E. Brunner, The Church's Witness to God's Design, vo1. 11 of Man's Disorder and God's Design (Ams terdam Assembiy Series) (New York: Harper and Row, Publishers, 1949), p. 81. For Sermon Starters on these axioms see M. R. Abbey, Preaching to the Contemporary Mind (Nashville: Abingdon Press, 1963), pp. 158-187. The following are similar assumed societal values: (1) its the surrounding that gives life its meanings; (2) religion's allright in its place, but that isn't in politics; (3) immortality is just your influence going on in the world; (4) these days you have to become a martyr to make the Christian religion real and I don't have a. martyr complex; (5) we must do what is right--to keep other people on our side; (6) you deserve the best; you owe yourself easy-chair comfort--forget the discomforts of others and live it up; take care of number one; (7) is it right? We'11 take a vote and see; (8) certainly we need it; they have one next door; (9) what's new must be good, what's old can't be; (10) who is God, that we are mindful of Him? Ibid., p. 75.

1E. A. Nida, Customs and Cultures (Pasadena, California: William Carey Library, 1954), p. 28.

2J. L. Springer, "West Indian Value System and the Church's Validating Role," Troubling of the Waters, p. 126. 
are prized in the West Indies, and particularly Jamaica, and will isolate a few.

Looking at the family patterns in the Caribbean, it is obvious that Christian marriage as a value is being seriously challenged. Up to 1973, recent studies have indicated that there is an illegitimacy rate in Caribbean countries ranging from 42 percent to 74 percent. Although we are aware that illegitimacy is not necessarily an indication of the percentage of unmarried persons or families in our society, yet hardly any territory boasts of a Christian-marriage family rating of above 35 percent. If it is true therefore that some 70 percent of the families of the Caribbean are living in common-law, a visiting relationship, or some other form of loose union, we may safely infer that Christian marriage is not the preferred pattern. ${ }^{1}$ As a pastor in Jamaica for a number of years, I suggest that what is stated above is very close to the Jamaican situation.

The following four tables have serious and far reaching implications for the family and for the Christian church.

It is of interest to note the following with regards to the statistics in table 1: (1) that among those who are still legally married, a considerable number are no longer living with their husband or common-law partners; and (2) that of many who have never been married, over 25 percent are living with common-law partners.

The statistics on table 2 reveal the following facts: (1) the divorce rate is higher between the ages of 20 and 34 for both men and

IIbid., p. 133. 
TABLE $1^{1}$

FEMALES FOURTEEN YEARS OF AGE AND OVER, CLASSIFIED BY UNION STATUS AND LEGAL

MARITAL STATUS, 1960

\begin{tabular}{lrrrrr}
\hline \multirow{2}{*}{ Union Status } & \multicolumn{5}{c}{ Legal Marital Status } \\
\cline { 2 - 6 } & $\begin{array}{c}\text { Never } \\
\text { Married }\end{array}$ & $\begin{array}{c}\text { Still } \\
\text { Married }\end{array}$ & $\begin{array}{c}\text { Now Sep- } \\
\text { arated }\end{array}$ & $\begin{array}{c}\text { Now Di- } \\
\text { vorced }\end{array}$ & $\begin{array}{c}\text { Now } \\
\text { TOdowed }\end{array}$ \\
\hline & 330,000 & 146,800 & 3,800 & 2,100 & 37,500 \\
$\begin{array}{l}\text { Never lived with } \\
\text { partner }\end{array}$ & 186,200 & 700 & - & - & 400 \\
$\begin{array}{l}\text { Living with husband } \\
\begin{array}{l}\text { Living with common- } \\
\text { law partner, no } \\
\text { longer with husband }\end{array}\end{array}$ & - & 133,300 & - & - & - \\
$\begin{array}{l}\text { or common-law } \\
\text { partner }\end{array}$ & 91,500 & 1,500 & 500 & 300 & 1,700 \\
$\begin{array}{l}\text { Not stated } \\
\text { Not }\end{array}$ & 44,000 & 10,400 & 3,200 & 1,800 & 35,400 \\
\hline
\end{tabular}

women, but is highest for women under 19; (2) that the divorce rate is highest among the young couples living together for a number of years; and (3) that the older the couples are when married, the less divorce occurs.

Values regarding the Christian marriage are even more crucial when we look at the grounds for divorce, as shown in tables 3 and 4.

1 Tables 1-4 are taken from the Statistical Yearbook of Jamaica, 1974 (Jamaica: The Printing Unit, Department of Statistics, 1974), pp. 215-225. 
TABLE 2

DIVORCES BY DURATION OF MARRIAGE AND AGE

OF PARTNERS AT MARRIAGE, 1973

\begin{tabular}{|c|c|c|c|c|c|c|c|c|c|}
\hline \multirow{3}{*}{$\begin{array}{c}\text { Duration } \\
\text { of } \\
\text { Marriage } \\
\text { (Years) }\end{array}$} & \multirow{3}{*}{$\begin{array}{l}\text { All } \\
\text { Ages }\end{array}$} & \multicolumn{8}{|c|}{ Age of Partner at Marriage } \\
\hline & & $\begin{array}{l}19 \mathrm{yr} \\
\text { under }\end{array}$ & $20-24$ & $25-29$ & $30-34$ & $35-39$ & $40-49$ & $\begin{array}{l}50 \& \\
\text { Over }\end{array}$ & $\begin{array}{c}\text { Not } \\
\text { Stated }\end{array}$ \\
\hline & & \multicolumn{8}{|c|}{ Wife } \\
\hline $\begin{array}{l}\text { Tota } 1 \\
\text { Divorces }\end{array}$ & 644 & 101 & 272 & 130 & 51 & 32 & 18 & 4 & 30 \\
\hline $\begin{array}{l}2 \text { yrs \& } \\
\text { under }\end{array}$ & 3 & 1 & 1 & 1 & - & - & - & - & - \\
\hline 3 yrs & 15 & 4 & 6 & 3 & 1 & 1 & - & - & - \\
\hline 4 yrs & 31 & 4 & 11 & 6 & 2 & 2 & - & - & 4 \\
\hline 5 yrs & 29 & 9 & 9 & 7 & - & 2 & 1 & - & 1 \\
\hline 6 yrs & 31 & 2 & 15 & 8 & 1 & 1 & 1 & 1 & 2 \\
\hline 7 yrs & 34 & 6 & 13 & 8 & 4 & 2 & - & - & 1 \\
\hline 8 yrs & 41 & 7 & 14 & 8 & 3 & 1 & 3 & 1 & 4 \\
\hline 9 yrs & 40 & 9 & 14 & 9 & 2 & 3 & - & - & 3 \\
\hline $10-14$ yrs & 160 & 30 & 68 & 31 & 7 & 7 & 6 & - & 11 \\
\hline $15-19$ yrs & 114 & 14 & 50 & 21 & 12 & 7 & 4 & 1 & 5 \\
\hline \multirow[t]{2}{*}{$\underset{\text { over }}{20 \text { yrs \& }}$} & 146 & 15 & 71 & 28 & 19 & 6 & 2 & - & 5 \\
\hline & & \multicolumn{8}{|c|}{ Husband } \\
\hline $\begin{array}{l}\text { Total } \\
\text { Divorces }\end{array}$ & 644 & 11 & 150 & 227 & 97 & 45 & 35 & 14 & 35 \\
\hline $\begin{array}{l}2 \text { yrs \& } \\
\text { under }\end{array}$ & 3 & - & 1 & 1 & - & 1 & - & - & - \\
\hline 3 yrs. & 15 & - & 6 & 5 & 2 & - & 1 & 1 & - \\
\hline 4 yrs & 31 & - & 10 & 8 & 4 & - & 4 & 1 & 4 \\
\hline
\end{tabular}


TABLE 2-- Continued

\begin{tabular}{|c|c|c|c|c|c|c|c|c|c|}
\hline \multirow{3}{*}{$\begin{array}{c}\text { Duration } \\
\text { of } \\
\text { Marriage } \\
\text { (Years) }\end{array}$} & \multirow{3}{*}{$\begin{array}{l}\text { All } \\
\text { Ages }\end{array}$} & \multicolumn{8}{|c|}{ Age of Partner at Marriage } \\
\hline & & $\begin{array}{c}19 \text { yr } \\
\text { \& } \\
\text { under }\end{array}$ & $20-24$ & $25-29$ & $30-34$ & $35-39$ & $40-49$ & $\begin{array}{l}50 \& \\
\text { Over }\end{array}$ & $\begin{array}{l}\text { Not } \\
\text { Stated }\end{array}$ \\
\hline & & & \multicolumn{7}{|c|}{ Husband } \\
\hline 5 yrs & 29 & 2 & 10 & 6 & 5 & 2 & 2 & 1 & $\varphi^{r}$ \\
\hline 6 yrs & 31 & - & 13. & 8 & 4 & 1 & 2 & 1 & 1 \\
\hline $7 \mathrm{yrs}$ & 34 & 1 & 15 & 7 & 6 & 3 & 1 & - & 1 \\
\hline 8 yrs & 41 & 1 & 13 & 11 & 4 & 4 & 2 & 2 & 4 \\
\hline 9 yrs & 40 & 2 & 12 & 13 & 1 & 4 & 4 & 1 & 3 \\
\hline $10-14$ yrs & 160 & 2 & 44 & 58 & 23 & 10 & 10 & 3 & 10 \\
\hline $15-19$ yrs & 114 & 1 & 26 & 49 & 14 & 9 & 5 & 4 & 6 \\
\hline $\begin{array}{l}20 \text { yrs \& } \\
\text { over }\end{array}$ & 146 & 2 & 30 & 61 & 34 & 11 & 4 & - & 4. \\
\hline
\end{tabular}

Looking at tables 3 and 4 we discover that the two ranking factors which contribute to divorce are desertion and cruelty. This trend is prevalent among the younger couples between ages 19 to 34 for women and 20 to 39 for men. From the foregoing it becomes obvious that the Christian church needs to take a hard look at the values of the family in the Caribbean and, in particular, in Jamaica.

A report of the consultation on the church's responsibility to the famity in the Caribbean, held in Barbados in June 1971, declares:

We feel that there is still room for the development of a more positive ministry to people who live in non-legal unions. It has disturbed us, for example, to note that the child of a nonlegal union still suffers legal and social disabilities and in some cases, churches continue to discriminate against illegitimate children... it is clear that a large portion of our people have not received the full ministry of the churches. 1

1 Ibid., p. 134. 
TABLE 3

NUMBER OF DIVORCES CLASSIFIED BY GROUNDS ON

WHICH DECREE ABSOLUTE IS GRANTED AND AGE

OF FEMALE PARTNERS AT MARRIAGE, 1972

\begin{tabular}{|c|c|c|c|c|c|c|}
\hline \multirow{2}{*}{$\begin{array}{l}\text { Age } \\
\text { Groups }\end{array}$} & \multicolumn{6}{|c|}{ Grounds for Divorce } \\
\hline & Total & Desertion & Cruelty & Adultry & Insanity & Other \\
\hline Al1 ages & 598 & 373 & 84 & 33 & 2 & 166 \\
\hline Under 19 & 97 & 47 & 20 & 5 & - & 25 \\
\hline $20-24$ & 230 & 115 & 40 & 10 & 1 & 64 \\
\hline $25-29$ & 134 & 65 & 12 & 11 & 1 & 45 \\
\hline $30-34$ & 71 & 42 & 9 & 2 & - & 18 \\
\hline $35-39$ & 29 & 18 & 2 & 1 & - & 8 \\
\hline $40-44$ & 8 & 5 & 1 & - & - & 2 \\
\hline $45-49$ & 2 & 1 & - & - & - & 1 \\
\hline $50-54$ & 2 & 2 & - & - & - & - \\
\hline 55 \& over & 1 & 1 & - & - & - & - \\
\hline No status & 24 & 17 & - & 4 & - & 3 \\
\hline
\end{tabular}

TABLE 4

NUMBER OF DIVORCES CLASSIFIED BY GROUNDS ON

WHICH DECREE ABSOLUTE IS GRANTED AND AGE

OF MALE PARTNERS AT MARRIAGE, 1972

\begin{tabular}{|c|c|c|c|c|c|c|}
\hline \multirow{2}{*}{$\begin{array}{l}\text { Age } \\
\text { Groups }\end{array}$} & \multicolumn{6}{|c|}{ Grounds for Divorce } \\
\hline & Total & Desertion & Cruelty & Adultery & Insanity & other \\
\hline All ages & 598 & 313 & 84 & 33 & 2 & 166 \\
\hline Under 19 & 9 & 6 & 1 & 1 & - & 1 \\
\hline $20-24$ & 183 & 89 & 35 & 11 & 1 & 47 \\
\hline $25-29$ & 178 & 92 & 21 & 8 & 1 & 56 \\
\hline $30-34$ & 90 & 46 & 14 & 5 & - & 25 \\
\hline $35-39$ & 61 & 35 & 4 & 1 & - & 21 \\
\hline $40-44$ & 31 & 16 & 6 & - & - & 9 \\
\hline $45-49$ & 10 & 5 & 2 & 1 & - & 2 \\
\hline $50-54$ & 3 & 2 & - & - & - & 1 \\
\hline $55 \&$ over & 9 & 5 & 1 & 2 & - & 1 \\
\hline No status & 24 & 17. & - & 4 & - & 3 \\
\hline
\end{tabular}


Proper planning before marriage and the instilling of the sacredness of marriage can help prevent young people from marrying too early and ending in a divorce. ${ }^{1}$ The men or women who break up their families through desertion or cruelty need to be addressed with the idea of individual responsibility, the sanctity of 1 ife, love, et cetera. The church may have to reassess its whole concent of proclamation, thus taking a broader interpretation, say, of Christian witnessing and evangelism.

Christian witnessing and evangelism are generally seen in the light of the distribution of tracts and the giving of Bible studies and preaching. I am advocating that this insular definition of witnessing be enlarged to include the matter of teaching families how to prepare for marriage, how to improve diet and health care, to have a knowledge of family planning, and many other things that lead to a better quality of life. This is part of the preacher's and the church's responsibility. This is a nart of biblical preaching which is rooted in the whole counsel of God.

Not only should the value of the family be emphasized by the Christian church, but consideration should also be given to the values of music and liberation and their importance to the Jamaican life. People in the Caribbean have learned to express themselves through the great "Spirituals" and the "Folk song." The sp̣irutuals were born under the strain of slavery and indentured labor. "Nobody knows the trouble I see, Glory Hallelujah!" "Swing low sweet chariot," et

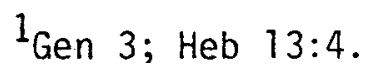


cetera, were born out of the Black experience.

While I am not trying to disqualify the great music masters (they still appeal to many of the Jamaican people), I am raising the question: Should Mozart, Bach, Chopin, and certain hymns and songs be preferred above the songs that say something to the Jamaican life? The church needs to address itself to this issue. And even more crucial is the issue of the relationship of the merriment of the Calypso and the rhythm of the Regge. The preacher must be prepared not only to see a point of contact in culture, but he must also be brave enough to do battle when the point of contact becomes a point of conflict. In other words, to preach effectively to contemporary man, the preacher must challenge the values that exist in society. This ought to be so with all values, be they marriage, music, or liberation.

The liberation of the human person--body, soul, and spirit--is a comparatively new value in the Caribbean. The people of the Third World countries, and in particular in the Caribbean, are seeing themselves as free people. There is a self-discovery, a uniqueness and identity of personhood. The Christian preacher can preach in this context. He can ally himself with this "freedon concept" through the doctrine of creation and then enlarge upon this through the doctrine of the incarnation and divine reconciliation.

What part can the preacher, through the gospe1, play regarding stereotype values? Springer has made this point:

Stereotype has perhaps done more harm to lest Indians and other non-European peoples of the world than anything else. For example, it has been said that the Amerindian cannot hold his liquor, the Black man is lazy, and the East Indian is dirty. These are not values but stereotypes originating first from the 
practice of the European of pre-judging everyone else without taking the trouble to get to know him. 1

Since stereotypes are still in the Jamaican society, the preacher ought to relate the gospel to this situation. And this is a crucial need that cannot be neglected. This false concept can be reversed by showing the value of each person and that Christ died for all. A healthy self-concept must be fostered in people. The preacher can help to reverse these stereotype values through the proclamation of the doctrines of creation, the incarnation and redemption. In a practical way the preacher can even do what the "Black Church" in America has done to reverse stereotype values--sessions held where the congregation is invited to join in chanting repeatedly: "I AM SOMEBODY! I AM SOMEBODY!"

It must also be stated that the real truth about a society is through its literature. Over the past several decades the Caribbean man has been on a desperate spiritual search. This is made evident by his literature. ${ }^{2}$ In Jamaica, this is also true. We will look at two examples from Jamaica's point of view. Louise Bennett has been described as Jamaica's leading comedienne, as the "only poet who has really hit the truth about her society through its own language," and as an important contributor to her country of "valid, social document,

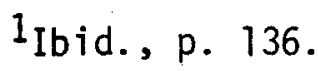

${ }^{2}$ Rohlehr has demonstrated convincingly that Caribbean literature since the 1930s, but more particularly since the 1950s, has been a deepening and prolonged exploration of Caribbean society, politics, and the inexhaustible recesses of the psyche of the Caribbean people. For an indepth study on this issue see Troubling of the Waters, pp. 187-205. 
reflecting the way Jamaicans think and feel and live."1 In Jamaica Labrish, Louise Bennett has been able to capture all the spontaneity of the expression of the Jamaicans' joy and sorrow, his ready, piognant, and even wicked wit, his religion, and his philosophy of life (emphasis mine). ${ }^{2}$ Jamaican Labrish is one grand potpourri of poems in which Bennett has concentrated on the immediacy of the task of having to survive. ${ }^{3}$ since the book reveals so much about the Jamaican life, it can serve as a point of contact or conflict for preaching.

An important segment of the Jamaican population which the Christian church can no longer ignore is the over seventy thousand Rastafarians. This is a vibrant movement to which the gospel must be presented. The Rastafarians are a classic example of a people who are in search of religious values, in search for identity. It means therefore that the book Dread, the Rastafarians of Jamaica could serve a very useful purpose to the preacher, either as point of contact or conflict.

\footnotetext{
i Jamaica Labrish (Great Britain: Collins Clear-Type Press, 1966), p. 5 . ${ }^{2}$ Ibid., p. 5.

3Ibid., p. 24. The late thirties and early forties are summed up in two words, "hard times." Note the way Bennett comments on the above periods of time in her poem "Hard Time." This is applicable to the present Jamaican scene. The poem is quoted in part.
}

\section{(1)}

Wat a pity, po' Miss Matty!

She dah-halla like ram-goat

Sey she try fe stretch her wages

And tear up de one-poun (dollar) note!

Po' ting! De cos o'livin, eena Everybody shut

And all de sinting dem dah-sell

Fe ten time wha dem wut!
(3)

Sal-fish and rice an flour! Even Brown soap get so high, Ef yuh noh know de chiney-man Yuh kean get piece fe buy!

Noh bada call ${ }^{(4)}$ fe steak or stew Ena no butcha shop, Ef yuh noh know de butcha well Yuh raise so-so scrap-scrap!

Ibid., pp. 119-120. 
VI. AN APPLICATION OF THE BIBLICAL MESSAGE

WITHIN THE JAMAICAN MILIEU

This section attempts to set the teaching of the redemptive activities of God, the meaning of the Kerygma, and the Kingdom of God motif in Jesus' parables within the Afro-Jamaican religious experience. The redemptive activities of God, which are set in bold relief in the book of Exodus and runs through the entire Bible, will be presented within the context of "liberation theology."

A preliminary statement is necessary with respect to the expression "liberation theology." I am not concerned with political.subjects couched in the guise of a calculated theological vocabulary. In other words, this is not an emotional pretext for plotting a social revolution. An authentic theology of liberation has to be founded on the immovable pillars of the Christian faith. ${ }^{1}$ God said that He would deliver Israel out of the hand of the Egyptians.

However, an authentic theology of liberation cannot escape the

1A. L. Trujil10, Liberation or Revolution? (Indiana: Our Sunday Visitor, 1977), p. 27. Liberation is a value which underties all the Scriptures. We can verify the etymology of certain terms: găal-pãdah, in Hebrew, means "to buy" as well as "to 7iberate." In the ethnic context of Palestine, it supposedly meant that you should rescue the one who had been sold by paying for him (Lev $25: 3,37$ ). In the Septuagint these ideas are expressed by apolutrosis--as in the rescue of a captive in Exodus: "I will rescue you by my outs tretched arm and with mighty acts of judgment. Know that I am Yahweh/the Lord/" (Exod 6:6). This idea is translated as redemptio in Latin, which more precisely means "to liberate." Among the words redemption, liberation, and salvation, then, there exists the most intimate connection. Ibid., pp. 14, 15. 
reality of the human situation in which God meets people. Therefore, a theology of liberation will be viewed in this meaning.

\section{Liberation Theology and the Afro-Jamaican Religious Experience}

The biblical tradition of God acting in history to deliver his people both from spiritual and physical oppression is revealed in the Exodus tradition and throughout the Bible. But it was left for the New Testament to apply the physical redemption to a moral and spiritual liberation.

Yahweh acted on behalf of His people freeing their spirits so that they could worship him. Not only did this very deed of God of liberating Israel form the core of Israelite confession, but this deed distinguished Yahweh from "other gods," as expressed in several old hymns such as Ps 82 and 68:5-6. This central theological motif also appears to be the cornerstone of the theology of election, as developed in Deuteronomy. ${ }^{1}$

But we must take into account that this liberating act of God is in itself a salvific and religious event that encompasses social and political dimensions. ${ }^{2}$ The Exodus tradition stresses the fact that the people that came from Egypt were an enslaved and oppressed minority who could do nothing for their own salvation but to cry out to the God of the fathers. ${ }^{3}$ This conviction that it was Yahweh who fought

$1_{\text {Deut }}$ 7:7.

${ }^{2}$ Truji11o, pp. 15, 16.

3Exod 3:9. 
their cause was expressed in Israel's confession as in Pss 77 and 136. What are the implications here for Jamaica? First, with respect to Israel's deliverance from physical bondage: Any serious consideration of proclamation in Jamaica must come to grips with an extension of this concept--Christ is the spiritual Moses whose spiritual manifesto for freedom is "to proclaim release to the captives." I This is particularly relevant to Jamaica which was a slave colony.

At the heart of God's liberating activities is the Kerygma. Through His death, resurrection, and exaltation, freedom from sin has been made possible. Johnson explains:

Jesus is the liberator. He is the revelation of the wisdom, the power and the love of God. This was the message which the early Christian preachers were commissioned to proclaim. This message was called the Kerygma. We preach Christ, Paul shouts. At the heart of the Kerygma lies this fundamental christological affirmation: Jesus is Liberator! Jesus is the Emancipator!?

This kind of Jesus needs to be presented or re-emphasized to Jamaicans because of the realities that prevail in the country at present. The christological titles are applicable to the Jamaican situation in a special way. The verbal functions and not the substantive implications are the crucial issues. Thus Christos may be seen as the One in whom and through whom Yahweh is to establish His

1Luke 4:18, 19. By implication, if Christ is the spiritual Moses, then crime, violence, and any evil system--be it socialism or capitalism could be Pharaoh. Some may even see the white man as Pharoah.

$2 p$. Johnson, Jr., "Jesus the Liberator," The Black Experience in Religion (New York: Anchor Press Doubleday, 1974), p. 127. 
sovereignty. The title "Son of God" is more functional in that it suggests the office and work of the Liberator rather than a mere description of His metaphysical nature. Immanuel means "God with us," while Kyrios describes the One who rules over the church, and Saviour points to the One who is to bring healing, salvation, and liberation for which mankind yearns.

These emphases in preaching are needed in the Jamaican society. Many Jamaicans need to hear a reassuring word that Christ can free the human spirit from physical and spiritual bondage. So Christos, Immanuel, Kyrios, and Saviour are christological titles that have fundamental significance for Jamaica at the present time. God through Christ will establish His eternal kingdom; Immanuel is with them in the present social, political, and economic crises; the Lord still rules in the affairs of people; and the Saviour can bring healing.

Second, Israel's deliverance was brought about without military intervention or revolution as we know them today. Recently there has been a spate of crime and violence in Jamaica where many people have lost their lives. An authentic theology of liberation is opposed to the spirit of political activism that is accompanied by violence. Therefore the church and, in particular, the preacher in Jamaica has a special role to play in the keeping of the peace. The sword of the Zealots is counter-productive, and this the church must assert. And yet, the attitude of the church should not be one of non-involvement. In both the 01d and New Testament there are rights and duties of the

$1_{\text {Emil }}$ Brunner, The Christian Doctrine of Creation and Redemption (London: Lutterworth Press, 1952), p. 272. 
liberated members of God's new community towards the poor, the outcasts, the oppressed, the exploited. A point for reflection might well be, Do oppression and violence reign when the church is silent? The church cannot be like the Essenes of old, who had settled in the desert awaiting God's judgment to fall on their enemies, or like the Pharisees, who remained physically in society, but concerned themselves exclusively with religious matters.

The Christian church is neither to flee the world nor to participate in its sinfulness. Rather, it is called to be "salt" and "light." If there are crime and violence in society, the church must speak out against these things.

So then, if the church's influence is to be felt, it cannot afford to be silent. And if the church has nothing to do with this "worldly" world, the world will have nothing to do. with the church.

A third point that needs to be considered is that the God who acts in history--secular and sacred--is the God who controls history. The masses of Jamaicans are confused, frustrated, and disappointed over the political status quo. Every sector of the society is affected. At present, the economic situation is not one to be desired. Over the past years there are those (for example, Norman Girvin ${ }^{1}$ ) who called for Jamaica to break ties with the multinational aluminum company system. However, the political leadership is calling for re-negotiation of the transaction. ${ }^{2}$ At this crucial stage of

$1_{\text {Norman Girvin, "Making the Rules of the Game," Social and }}$ Economic Issues, Decenber 1971, quoted in Stone, p. 751.

2 Michael Manley, The Politics of Change, A Jamaican Testament (Washington, D.C.: Howard University Press, 1975). 
Jamaica's history, the urgency of Christian hope could be decisive. This theology of hope should be an active and creative one, a hope that embraces the reality of the this-worldly and the other-worldly. The "now" and the "then" are two poles of one reality.

In the fourth place, a theology of liberation sees God as a just and righteous God who punishes the oppressor. "He rules in the kingdom of men and gives it to whom He will." 1 A part of the eschatological task of God's liberated community is to proclaim the termination of all earthly and oppressive powers. This can be done by a liberated community, His new creation, under the rule of the Messiah: "A community with no arms at their disposal, but only the rod of their lips and the breath of their mouths."2 This is done in love. This is the risk of prophetic proclamation.

However, the most radical and far-reaching form of church involvement in matters of government is intercession. ${ }^{3}$ This is a conscious response on the part of the church to Christ's command: "Love your enemies and pray for those who persecute you. "It is important to note that Christ in quoting from Isaiah omits any reference to the "day of vengeance of our God." 5 He proclaims only the message of grace, not vengeance. In the light of the foregoing, this is one of the paradoxes of proclamation. The preacher's main task is to proclaim

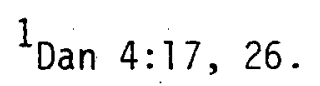

${ }^{2}$ F. Deist, "The Exodus Motif in the 0ld Testament and the Theology of Liberation," Mlissionalia, 5 (The South African Missiological Society, August 1977): 69.

$$
{ }^{3} 1 \text { Thess } 5: 17 . \quad{ }^{4} \text { Matt } 5: 44 . \quad{ }^{5} \text { Is a } 61: 2 .
$$


Christ, but proclaiming Christ also means the destruction of evil at the eschaton.

So far, we have been discussing a theology of liberation and the Afro-Jamaican religious experience. Not only are God's redemptive activities other-worldly, they are also this worldly in that He entered history. This is significant to Jamaica, as we have seen. In a final section the Kingdom of God motif in the parables of Jesus with respect to Jamaica is examined.

$\frac{\text { The Kingdom of God Motif in Jesus' Parables }}{\text { with Respect to Jamaica }}$

The emphasis must be on "Kingdom" and "parables." As a point of departure I would like to suggest that the gospel events as revealed in the parables are normative for the Christian life. It means that the closer a contemporary event or situation (e.g. Jamaica) comes to resemble the social and spiritual realities of the gospel event, the more it stands in the line of the gospel. The parables arose out of an historical situation. In addition, the parables of Jesus are concerned with riches and poverty, wages and coin--the overriding questions of subsistence and survival.

As noted, the parables must be seen in the light of their historical situation and are normative for contemporary life. Two models for the earthly ministry of Jesus will be examined, Galilee and Jerusalem. Galilee was the main scene of Christ's activity. Not only was He reared in Galilee, but most of His apostles came from there. Galilee was predominantly a Gentile country. Consequently, it 
could fittingly be called "Galilee of the nations." 1 Jerusalem was the city of the great king. ${ }^{2}$ Galilee in the North was rustic and the population had a distinct accent, perhaps even a different dialect. ${ }^{3}$ Jerusalem in the South presented an intelligible historical picture and a linguistic texture as lingua franca. ${ }^{4}$ Jamaica has its Galilee and its Jerusalem; its sophisticated city life and its rustic setting. This has implications for proclamation. The preachers.' approach and, in a special way, the church's, as a cooperate body, should be in keeping with the setting. In other words, the church's method and kind of ministry will be affected by the social and cultural influence of a place. To be specific, the kind of work that is being carried on in Kingston and Montego Bay, Jamaica, should have a characteristic difference from the work and ministry carried on in Falmouth or Hopewel1, Jamaica. These distinctions have relevance for the preachers: style of delivery as well as the content of his message.

Jesus taught in parables for many reasons, and the contemporary preacher needs to look at some of these reasons.

1. In many hearts the truth had taken little root and it had been quickly caught away. "Therefore speak I to them in parables,"

Isa $9: 1$; Matt $4: 15$.

2 Matt 20:18; Mark 10:32; Luke 18:31.

3 Mark 14:70; Luke 22:59.

4J. P. Brown, "Techniques of Imperial Control: The Background of the Gospel Event," The Bible and Liberation (Berkley, California: The Community for Religious Research and Education, 1976), p. 32. 
for He said: "Because they seeing see not; and hearing they hear not ..." (ilatt 13:13-15).

2. Parable teaching was popular in Christ day and commanded the respect and attention, not only of Jews, but of the people of other nations. No more effective method of instruction could have been employed.

3. Christ had truths to present which certain people in His audience were unprepared to accept or even to understand. For this reason also He taught them in parables.

4. Among the multitudes were enemies who wanted to find some accusation against Him. Therefore, the Saviour presented truth in such a way that His enemies could find nothing against Him.

5. In parables Christ rebuked the hypocrisy and wicked works of those who occupied high positions, and in figurative language clothed truth of so cutting a character that had it been spoken in direct denunciation, they would have put an end to His ministry.

6. In the Saviour's parabolic teaching is an indication of what constitutes the true "higher education." Christ did not deal in abstract theories, but in that which is essential to the development of character. He spoke to men of those truths that relate to the conduct of life and that take hold upon eternity. ${ }^{1}$ The preacher's method of presentation will be more effective if he takes seriously these implications for preaching.

A serious reading of the gospel narrative would suggest that

$1_{\text {Ellen }}$ G. White, Positive Christian Living (Washington, D.C.: Review and Herald Publishing Association, 1952), pp. 9-17. 
the parables give special attention to economic realities as a major emphasis in His teachings about the Kingdom. Jesus' parables show a striking contrast between rich and poor. There were three social levels: the rich who benefitted from taxation or at least escaped it; the hardworking poor kept on subsistence by taxation; the destitute who had given up the unequal struggle. 1

The socio-economic climate in the time of Jesus would suggest that the political affairs were in a crisis. In the lifetime of Jesus, Galilee was ruled by Herod Antipas, called "King" by Mark. ${ }^{2}$ Antipas lived an immoral and luxurious $7 \mathrm{ife}, 3$ yet $7 \mathrm{ived}$ as an orthodox Jew, even attending feasts at Jerusalem. ${ }^{4}$ Jesus referred to him as a fox, ${ }^{5}$ and he is mentioned in the New Testament in connection with the imprisonment and execution of John the Baptist. 6

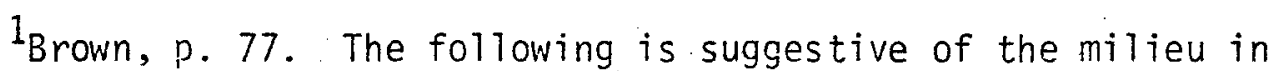
which Jesus spoke. Note the rich steward who, if fired, has the choice of manual labor or beggary (Luke 16:1-8); the beggars at Jericho (Mark 10:46); the Lazarus and Dives tale (Luke 16:19, 20); the big landowners building bigger barns (Luke 12:18); the rich neighbor (Luke 14:12); the rich landowners living at Tiberias or Jerusalem rented to tenants (llark 12:19); the estate being managed through stewards (Luke 12:35-48; Mark 13:33-38); the robbed estate (Luke 12: 39 ); note that a day's wage was a Roman denarius (Matt 20:2); that there were the mained, poor, b7ind (Luke 14:21, 23; were physical sufferings (one woman walked for twelve years, bleeding--Mark 5:25, 26); demonic possession, psychoratic diseases, and resistant movements (e.g., the zealots).

2Mark $6: 14$.

3 matt 14:1-12. He rebuilt Seppinoris in Galilee, added to its fortifications, and made it his capital. He also built Tiberias and other cities and strengthened the borders of his possessions. S. Horn, Seventh-day Adventist Bible Dictionary (Nashington, D.C.: Review and Herald Publishing Association, 1960), p. 462.

$$
{ }^{4} \text { Luke 23:7 } \quad{ }^{5} \text { Luke 23:13. 6Matt 14:3-12. }
$$


In the biblical models of Jerusalem and Galilee can be seen a striking parallel between many a rural and suburban area. Jamaica is no exception. It was in this type of socio-economic and political milieu that Jesus announced the inbreaking of his Kingdom through parables. What is this saying to the Jamaican situation? I am now proffering two concepts: a theology of hope and the necessity for moral, spiritual, and political confrontation.

It was pointed out earlier that Christ's parables are Kingdom oriented, and that the concept of the Kingdom is both present and future. The "already and not yet" are held in tension, and the element which links these two aspects of the Kingdom to one another is the Christian hope. When this is contextualized into the Jamaican society, it means that the proclamation of Christ's second coming to put an end to the uncertainty that exists will be one of the preachers' priorities. The consumation of the Kingdom of God in the parousia will be the beginning of a perfect freedom. ${ }^{1}$ This kind of preaching is eschatological because it affects people here and now with the "ultimate reality of their lives."2

And yet this Christian hope is active or else it is no hope. While authentic proclamation points to a God who will make all things new in the hereafter, it does not omit the "now." The Christian hope is both possession and yearning, response and activity, it is getting

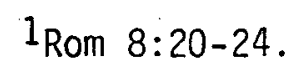

${ }^{2} R$. Buttmann, The Presence of Eternity: History and Eschatology (New York: Harper and Row, 1957), p. 180. 
involved in present history. It is essentially activity and commitment.

Does this mean that the preacher must get involved in the political affairs of his nation? Can he raise his voice on matters such as fair wages, or justice, or human rights? If the preacher takes his task seriously, and he needs to, and this must be true of the church as well, he will take a critical stance against injustice. ${ }^{1}$ He will bear in mind that man is a "theological category" because of his creation in God's image and because of the incarnation--God became man. On the basis of these two deeds of salvation man must concern himself with the liberation of others. This is the foundation for all Christian reflection on fundamental human rights. ${ }^{2}$

Finally, authentic proclamation is confrontational, morally, spiritually, and politically. It is not being suggested in the least that the church should leave her main task--that of getting a people ready for the Kingdom, but the church should also care for the social

$1_{\text {Rom }} 13$ and Rev 13 are significant chapters that the preacher and the church will want to bear in mind. Rom 13 was written in the period of transition from Claudius to Nero, under a reasonable government, in a time of relative political calm. Rev 13 was written in the period when Emperor Domitian oppressed his subjects, persecuted Christians, and usurped for himself divine characteristics. Where the state in Rom 13 is regarded as God's servant for the goal of its citizens, Rev 13 portrays it as the beast that has to be resisted. In Rom 13, the state is an instrument of law and justice. In Rev 13 it is inhuman and unjust. And yet, even in the case of Rom 13, unconditional obedience is not meant. Paul must have known about Moses who defied Pharoah, Samuel who rebuked Saul, Daniel and friends who opposed Nebuchadnezzar, Jeremiah and, particularly, all the prophets who denounced injustice, and Jesus who called Antipas a fox. See David J. Bosch, "The Church and the Liberation of Peoples," Missionalia, p. 21.

$$
\text { 2Ibid., p. } 34 .
$$


well-being of people. And it must remain the conscience of the state. When we summarize the application of the biblical message with respect to the Jamaican situation, we see the following points emerging: liberation theology takes seriously God's redemptive activities. Not only is it spiritual, it is also social. We have also seen that the parables of Jesus are Kingdom-oriented vis-a-vis the social economic background. In a country. like Jamaica where many people are undergoing tremendous economic and social frustrations, a theology of hope cannot be left off the Adventist preachers' agenda. The imminent return of Christ must be preached, calling people to a saving knowledge of Christ. The church must prepare a people to meet Christ.

And yet, proclamation cannot leave out the "this worldly" aspects of life. In Jamaica, the preaching of the Good News must come to grips with the people's economic, social, and political rights. For example, if someone is dishonestly dealt with in terms of illegal and unfair business practices, the preacher and the church in general can represent that one to the proper authorities, even to the extent of seeking legal redress for the individual who has suffered. This is a part of the priestiy and prophetic role of preacher and church. These are two ways of caring.

In essence then, the preaching in Jamaica must be seriously concerned with the whole man. This gospel, the redemptive act of God in Christ to meet the whole man, must be communicated in a unique way to the Jamaican context. 


\section{SUMMARY AND CONCLUSIONS}

We have discussed the Afro-Jamaican religious background noting that Jamaica is a multi-cultural, complex, and pluralistic society which has been greatly influenced by West Africans. The Good News must be communicated in this context. For the preacher to be effective, he must not only have a message but he must be conversant with the culture and the type of audiences that he engages with the gospel. For Jamaicans, preaching must assume the nature of biblical storytelling. Not only should the congregation hear the sermon, they must be able to see it, feel it. Their hearts must be lifted; their

feelings gripped. ${ }^{1}$ The preacher must dramatize the Good News.

It was shown that folk culture, dialogue, celebration, and the social and spiritual values must play an important part in the communication of the gospel to Jamaicans. Like the biblical writers who drew upon the existing culture in order to be relevant, the modern preacher will also preach to the times. Dialogue will be taken into consideration so that there can be an "I-Thou" relationship between pulpit and pew. Because of the expressiveness of the Black congregation, dialogue becomes an integral part of Black preaching. Finally, proclamation in Jamaica challenges the social and spiritual values, as point of conflict or contact.

1J. Russel, "The Minister as Artist," Christianity Today, (Washington, D.C.: 1962), 6:17. 
Any serious consideration of preaching in Jamaica must come to grips with a theology of liberation from a spiritual, moral, and physical point of view. At the very core of the Kerygma are the liberating activities of God in Christ. Against the Jamaican historical background, the Christ-event is especially relevant.

The Kingdom of God motif in the parables of Jesus when placed against the Jamaican setting was seen to suggest the emphasis of hope in light of the eschaton as well as confrontation of political and economic realities. The proclamation of the parousia must be on the agenda of the church as well as concern for present harsh realities. The gospel must address the whole man. The "other-worldly." and the "this-worldly" are two aspects of one reality.

\section{Conclusions}

For the preacher to be an effective proclaimer of the Good News, he must know it cognitively and, more so, affectively. His understanding of God's message should be biblically oriented. Without an understanding of God's liberating act with its impact upon his own spiritual life he is unprepared to communicate the gospel to his culture.

Holy history must meet personal faith. That is to say, faith and culture must meet. The preacher is caught between Barthian and Tillichian categories--the exclusive focus on the message or concern with culture. It is the greatest irony for the preacher to think that his job is complete when he exegetes and expounds the biblical message with almost no regard for his congregation's worldly life. This 
one-sided notion of preaching is Barthian. The preacher, and in particular the Jamaican preacher, will balance this approach with paying special attention to the culture. This is Tillichian.

Since preaching must move from the Bible to the culture, the Jamaican preacher will study the culture. And he will raise serious questions about his culture to which the gospel is to be addressed. At the same time, the positive cultural elements will be affirmed and built upon.

Finally, the Black preacher is forced to become an artist: "he joins things together," he "puts things together." In short, his work becomes a thing that has form and beauty. The Black preacher is like an architect in that he seeks to understand the meaningless lines, numbers, figures, and letters that are embedded in his cultures. The Black preacher is as a sculptor as he chisels the solid core of the abiding truths of God's Words, both for himself and his congregation. The Black preacher is like a musician who uses the gospel to touch hearts and creates a response with the listener. The Black preacher is as a painter. He first visualizes a scene: perhaps a sunset, a flower, or a mountain. Although he sees the whole scene, he narrows his sermons to meet the existential needs of his people. Then the Black preacher is like a dramatist who seeks to dramatize the great act of God in Christ to people. He sees his congregation as a slice of the drama of life--a life that is real, honest, and vital. 1

Through biblical storytelling, folkculture, dialogue

1). Rosse1, "The Minister as Artist," Christianity Today, 6:17. 
celebration, and parables, he communicates the Good News of the Kingdom. As one who has experienced the saving effects of the gospel he becomes God's man or woman helping to create order out of chaos. 
APPENDIX A

\section{A PARAPHRASE OF LUKE 22:54-62 IN CONTEMPORARY STYLE}

Peter had problems that morning early, as he stood in the palace courtyard. While Jesus was getting his gun-court trial justice inside, Peter was lonesome, and he looked around for his usual audience to lead. He had been accustomed to being recognized, and he had extreme ego needs. He had been the boss among the fishermen, and he was the leader of the disciples, next to Jesus. He enjoyed things like speaking to thousands and telling them to be seated.

The only folks around that morning were the ones standing by the fire. So he joined this bunch and started talking amd making his moves. Right away a girl spotted him for a Jesusite. Here he was, trying to sort of take over some new turf, and this janitor/helper has to spoil it all talkin' 'bout "This man was with Jesus." Peter spoke before he thought, and he said, "I don't even know the man."

We11, it worked for a little while, but somebody else accused him a little later of being from the Jesus bunch. Peter was so set on joining this new bunch that he blurted at the fellow: "Man, I am not!" So then he stood there and tried to work his way for a whole hour, and he thought he was getting away scotch free. But the people kept listening to his Galilian accent, and they knew something was wrong. Finally, somebody said, "Come on now, you were with him, for you are a 
Galilean, and your very talk gives it away and betrays you." Peter was really upset, and he cussed and swore (Matt 26:72) and said, "I don't know what you're talking about!" It was like saying, "Man, bel ieve me, I have never seen him before."

And just that second he heard the rooster crowing and he looked up just in time to see Jesus looking him dead in the eye. He remembered what Jesus had said, and he just couldn't stand it!

There 'was Jesus' sweaty brow silently saying, "I'm having an awful time, and even you've denied me." And there was his set jaw saying, "But I'm prepared for the worst, and I'll not give in." And worst of all there were Jesus' loving penetrating eyes. They spoke worlds of deep meaning. They said, "I know, Peter; I understand. Didn't I say it would be like this? But don't worry, Peter, I still love you anyway. Thanks, Peter, for even coming this far with me. Now goodbye, Peter," It was too much! Peter couldn't take it any more.

And Peter went out and cried like a baby. The big, strapping, cussing, talkative fisherman walked away and cried!

But he never denied Jesus again. He went back to his fishing, but in his next real test he said, "Let me tell you something. You can beat me if you want to, or even kill me. But the man was healed by Jesus. He's the one you big shots crucified; and He's like the stone that the builders rejected and is became the keystone of the 
arch. Now, go ahead and do what you want to do; I'll never deny him again (Acts $4: 5-12$ ) 1

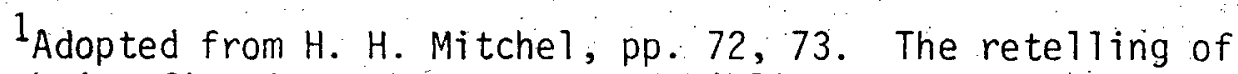
this nariative fits into the concept of biblical storytelling and serves as a fitting climax of celebration. 
APPENDIX B

TABLE $V$

A SAMPLE OF THE APOSTOLIC KERYGMA

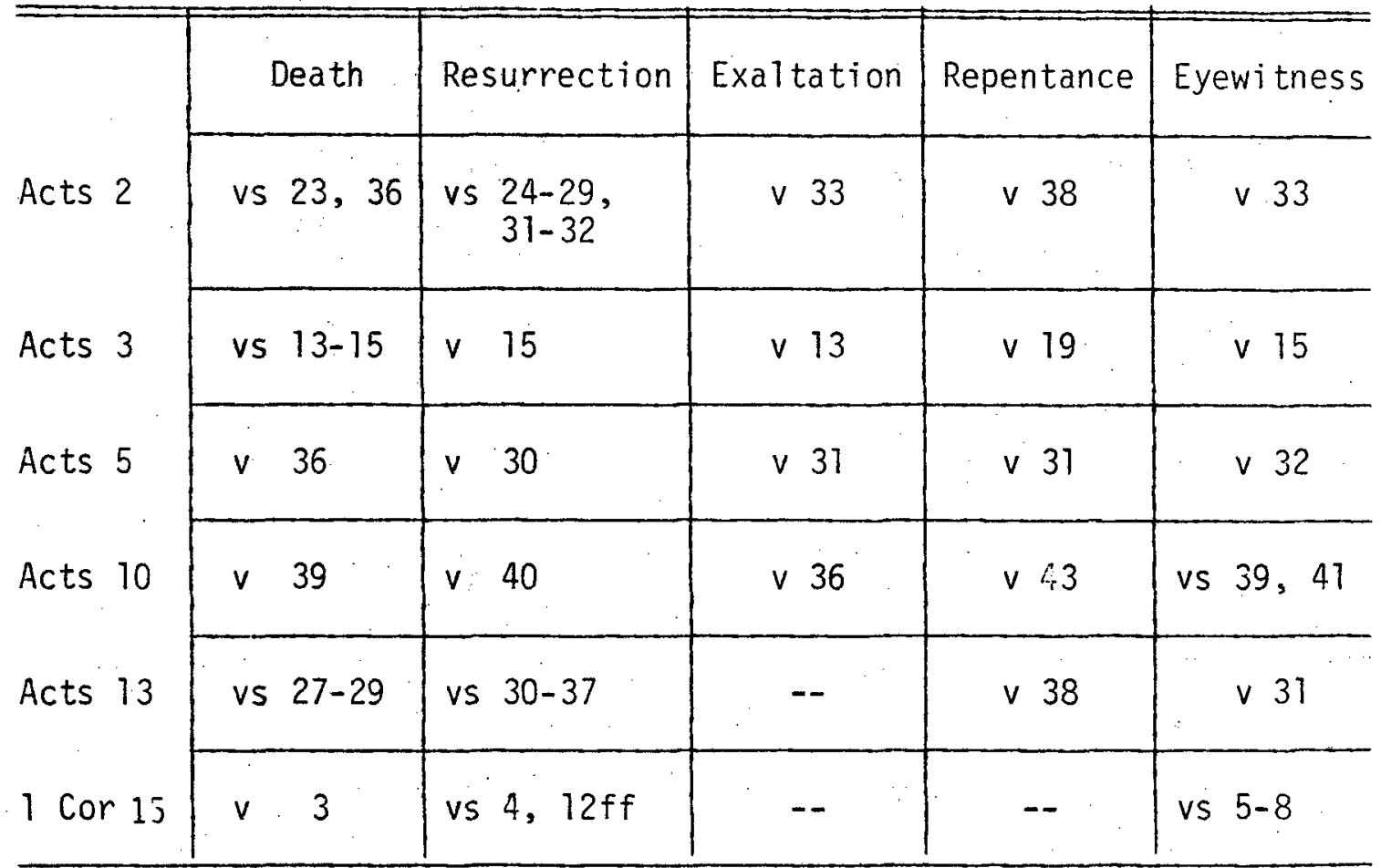

SOURCE: Adopted from C. H. Dodd. 


\section{SELECTED BIBL IOGRAPHY}

Abbey, M. R. Preaching to the Contemporary Mind. Nashville: Abingdon Press, 1963.

Achtemeier, E., and Achtemeier, Paul. To Save All People. Philadelphia: United Church Press, 1967.

Anderson, B. W., ed. The 01d Testament and the Christian Faith. New York: Harper and Row, 1963.

Asting, R. Die Verkundigung des Wortes in Ur-christentum /The Proclamation of the Word in the Early Church/. Stuttgart: W. Kohlhammer, 1939

Baird, W. "What is the Kerygma? A Study of 1 Cor $15: 3-8$ and Gal 1: 11-17." Journal of Biblical Literature. V01. 76. Philade1phia: The Society of Biblical Literature, 1957.

Barreth, L. E. Soul-Force: African Heritage in Afro-American Religion. New York: Anchor Press, 1974.

- The Sun and the Drum. Kingston, Jamaica: Sangster's Book Store, 1976 .

Barth, Karl. The Word of God and the Word of Man. Translated by D. Horton. New York: Harper and Brothers, Publishers, 1957. - The Preaching of the Gospel. Philadelphia: Westminster Press, 1963.

Buber, M. I and Thou. Translated by W. Kaufmann. New York: Charles Scribmer's Sons, 1970.

Beckwith, Martha. Black Roadways: A Study of Jamaica Folk Life. Chapel Hill, N.C.: University of North Carolina Press, 1929.

Behn, J. "Hermeneuō." Theological Dictionary of the New Testament. Grand Rapids: Wi Tliam B. Eerdmans Publishing Company, 1964, 2:661.

Bellon, I. Twi Lessons for Beginners. Accra, London: Longman, Green, 1963.

Bennett, L. Jamaican Labrish. Great Britain: Collins Clear-Type Press, 7966. 
Blackwood, A. W. Ezekiel, Prophet of Hope. Grand Rapids: Baker Book House, 1965.

Bonhoeffer, D. Letters and Papers from Prison. Edited by E. Bethage. New York: The Macmilian Company, 1964.

Bosch, D. J. "The Church and the Liberation of People." Missionalia 5 (1977): 21.

Braaten, C. E., and Harrisville, R. A. Kerygma and History, A Symposium on the Theology of R. Bultmann. New York: Abingdon Press, 1962.

Bright, John. The Authority of the 01d Testament. Grand Rapids: Baker. Book House, 1975.

Brown, J. P. "Techniques of Imperial Control: The Background of the Gospel Event." The Bible and Liberation. Berkley, California: The Community for Religious Research and Education, 1976.

Brunner, E: The Church's Witness to God's Design. Vol. 11 of Man's Disorder and God's Design. New York: Harper and Row, Publishers, 1949.

- The Christian Doctrine of Creation and Redemption. London: Lutterworth Press, 1952.

Bugge, C. A. Die Hauptparabeln Jesu /The Main Parables of Jesus T. Gressan: N.p., 1903.

Bultmann, R. Kerygma and Myth. Translated by R. H. Fuller. London: SPCK, 1954.

- The Presence of Eternity: History and Eschatology. New York: Harper and Row, 1957.

Catherial, G. A. "Freedom with Involvement.". Foundation--A Baptist Journal of History and Theology. Vol. II, No. 1. Rochester, New York: American Historical Society, 1968.

Conda 11, F. Jamaica Negro Proverb and Sayings. Kingston, Jamaica: N.p., 1910 .

Craddock, F. B. As One without Authority. Daklahoma: The Philips University Press, 1974.

Crum, M. Manual on Preaching. Valley Forge: Judson Press, 1977.

Davis, J. M. The Church in the New Jamaica. New York: The Acadenly Press, 1942. 
Davis, J. W. "George Liele and Andrew Bryan, Pioneer Negro Baptist Preachers." Journal of Negro History. Vol. 3. The Association for the Study of Negro Life and History, 1918.

Day, R. E. The Shadow of the Broad Brim. Philadelphia: The Judson Press, 1934.

Deist, F. "The Exodus Hotif in the 01d Testament and the Theology of Liberation." Missionalia 5 (August 1977): 69.

Diem, H. Dogmatics. Translated by H. Knight. Philadelphia: The Westminster Press, 1959.

Dodd, C. H. The Apostolic Preaching and Its Development. Hew York: Harper and Row, Publishers, 1964. - Parables of the Kingdom. New York: Charles Scribner's Sons, 7967 .

Driver, S. R. A Critical and Exegetical Commentary on Deuteronomy. New York: Charles Scribner's Sons, 1895.

Eissfeldt, 0 . The 01d Testament and Introduction. Translated by B. R. Ackroud. Oxford: Basil Blackwoods, 1965.

Eppinger, P. "Be Occupied with Preaching." Christianity Today 18 (June 1967): 113-114.

Fant, C. Bonhoeffer: Horldly Preaching. New York: Thomas Nelson Publishers, 1975 .

- Preaching for Today. New York: Harper and Row, Publishers, $197 \overline{.}$

Farmer, H. H. The Servant of the Word. London: Nisbeth and Company, 1946.

Fessenden, S. A.; Johnson, R. I.; Larson, P. M.; and Good, K. M. Speech for the Creative Teacher. Iowa: William C. Brown Company Pub7isher, 1973.

Flew, R. N. Jesus and His Church. Philadelphia: Abingdon Press, 1938.

Forsyth, P. T. Positive Preaching and the Modern lind. Grand Rapids: William B. Eerdmans, 1964.

Friedrick, r. "Kërussō." Theological Dictionary of the New Testament. Grand Rapids: William B. Eerdmans Publishing Company, $\overline{1976}, 3: 700$. 
Furnish, V.P. Theology and Ethics in Paul. Nashville: Abingdon Press, 1968.

General Facts on Jamaica. Kingston, Jamaica: The Agency for Public Information, 1975.

Girvin, iv. "Making the Rules of the Game." Social and Economic Issues. December 1971. Quoted in R. Stone, "A Black Liberation Theology from Jamaica." The Christian Century 91 (JuTy-December 1974): 750 .

Granskou, D. M. Preaching on the Parables. Philadelphia: Fortress Press, 1972.

Grasso, D. Proclaiming God's Message. Indiana: Notre Dame University Press, 1968.

Griffin, E. A. The Mind Changers: The Art of Christian Persuasion. I11 inois: Tyndale House Publishers, 1976.

Ha11, D. Free Jamaica, 1836-1865, An Economic History. New Haven: YaTe University Press, 1959.

Ha11, Thor. The Future Shape of Preaching. Philadelnhia: Fortress Press, 1973.

Hance, D. F. Theology of the 01d Testament. London: SPCK, 1976.

Harrison, R. H. An Introduction to the 01d Testament. Frand Rapids: William B. Eerdmans Publishing Company, 1969.

Hasel, a. F. Old Testament Theology. Grand Rapids: Nilliam B. Eerdmans Publishing Company, 1975.

Hauck, F. "Parabole." Theological Dictionary of the New Testament. Grand Rapids: William B. Eerdmans Publishing Company, 1964, $5: 747$.

Hill, R. Lights and Shadows of Jamaican History. Kingston, Jamaica: N.P., 1859 .

Holmes, E. A. Foundations: A Baptist Journal of History and Theology. Vol. 9. Rochester, New York: American Baptist Historical Society, January-March, 1966.

Horn, S. Seventh-day Adventist Bible Dictionary. Washington, D.C.: Review and Herald Publishing Association, 1960.

Howe, R. The Miracle of Dialogue. New York: The Seabury Press, 1963. An Hundredfold. Kingston, Jamaica: The Jamaica Baptist Union, 1949. 
Hunter, A. M. The Parables, Then and Now. SCM Press, 1971.

Jeky11, W. Jamaican Song and Story. New York: Dover Publications, 1966.

Jeremias, J. The Sermon on the Mount. Translated by H. Perrin. London: Oxford University Press, 1961. - The Parables of Jesus. Revised Edition. New York: Clarke Eurbner's Son, 1963.

Johnson, P. "Jesus the Liberator." The Black Experience in Religion. Ne:v York: Anchor Press Doubleday, 1974.

Johnston, R. M. "Parabolic Interpretation Attributed to Tannaim." Ph.D. dissertation, The Hartford Seminary Foundation, 1977.

Juilicher, A. The Parables of Jesus. Tubinden: N.p., 1970.

Kingsbury, J. D. The Parables of Jesus in Matt 13. Richmond, Virginia: Knox Press, 1969.

Kung, Hans. The Church. New York: Image Books, 1976.

Kuske, M. The 01d Testament as Book of Christ. Philadelphia: Westminster Press, 1976.

Ladd, G. E. The Presence of the Future. Grand Rapids: William B. Eerdmans Publishing Company, 1974.

Lenski, R. C. H. The Interpretation of St. Paul's First and Second Epistle to the Corinthians. Columbus, Ohio: The Artbury Press, 1943.

Luccock, H. E. In the Minister's Workshop. Nashville: Abingdon Press, 1944.

Manley, Michael. The Politics of Change, A Jamaican Testament. Washington, D.C.: Hanbid University Press, 1975.

Mbiti, J. S. African Religions and Philosonhy. New York: Anchor Books, Doubleday and Company, 1970.

Miller, R. G. Fire in Thy Mouth. Nashville: Abingdon Press, 1954.

Miskotte, K. H. When the Gods Are Silent. Translated with an Introduction by J. W. Doberstein. London: Collins St. James Place, 1967. 
Mitchell, H. H. The Recovery of Preaching. New York: Harper and Row Publishers, 1977.

Moore, J. G. "Religious Syncretism in Jamaica." Practical Anthropology 12 (1965): 71 .

Moore, R. "The Historical Basis of Theological Reflection." Troubling of the Waters. San Fernando, Trinidad: Rahaman Printery, 1973.

Morris, C. The Word and the Words. Nashville: Abingdon Press, 1975.

Mounce, R. M. The Essential Nature of New Testament Preaching. Grand Rapids: William B. Eerdmans Publishing Company, 1960.

Nichol; F. D., ed. Seventh-day Adventist Bible Commentary. 7 Vols. Washington, D.C.: Review and Herald Publishing Association, 1957.

Nida, E. A. Customs and Cultures. Pasadena, California: William Carey Library, 1954.

Neibuhr, H. R. Christ and Culture. New York: Harper and Row, Publishers, 1951 .

Owen, J. Dread, The Rastafarians of Jamaica. Backersville: Montrose Printery, 1976.

Palmer, E. Salvation by Surprise. Texas: Wordbooks, Publishers, 1975.

Pease, N.F. "Preaching and Biblical Intrepretation." A Symposium of Biblical Hermeneutics. Washington, D.C.: Review and Herald Publishing Association, 1974.

Perry, L. M. "Trends and Emphases in the Philosophy; Materials, and Methodology of American Protestant Homiletical Education as Established by a Study of Selected Trade and Textbooks Published between 1834 and 1954." Ph.D. dissertation, Northwestern University, 1961.

- Biblical Sermon Guide. Grand Rapids: Baker Book House, 1970 .

Pinnock, C. Biblical Revelation--The Foundation of Christian Theology. Chicago: lloody Press, 1971.

Pipes, William. Say Amen, Brother! Westport, Connecticut: Negro Universities Press, 1951.

Ramm, B. The Nitness of the Spirit. Grand Rapids: William B. Eerdmans Pub7ishing Company, 1960. 
Randolph, D. J. God's Party. Nashville: Abingdon Press, 1975.

Rice, C. L. Interpretation and Imagination. Philadelphia: Fortress Press, 1970.

Richardson, C. L. "The Foundations of Christian Symbols." Quoted in F. E. Johnson, ed. Religious Symbolism. New York: Institute of Religious and Social Studies, 1955.

Ridderbos, H. N. Coming of the Kingdom. Philadelphia: Presbyterian and Reformers Publishing Company, 1962.

Ritschl, D. A Theology of Proclamation. Richmond, Virginia: Knox Press, 1960.

Roberts, $H$. Jesus and the Kingdom of God. London: Epworth Press, 1955.

Robinson, E. A Greek and English Lexicon of the New Testament. New York: Harper and Brothers, Publishers, 1885.

Rohlehr, G. "flan's Spiritual Search in the Caribbean through Literature." Troubling of the Waters. San Fernando, Trinidad: Rahaman Printery, 1973.

Rosse1, J. "The Minister as Artist." Christianity Today 6 (1962): 17.

Russe11, $H$. "The Challenge of Theological Reflection in the Caribbean Today." Troubling of the Waters. San Fernando, Trinidad: Rahaman Printery, 1973.

Sandy, H., and Headram, A. C. A Critical and Exegetical Commentary on the Epistle to the Romans. Edinburgh: T \& T Clarke, 1958.

Schmitz, 0tto. "Parakeleō." Theological Dictionary of the New Testament. Grand Rapids: WiTliam B. Eerdmans Publishing Company, $\overline{1976}, 5: 799$.

Schweitzer, A. The Quest of the Historical Jesus. New York: Macmillan, 1968.

Sellers, J. E. The Outsider and the Hord of God: A Study in Christian Communication. Nashville: Abingdon Press, 1961.

Simpson, G. E. Religious Cults of the Caribbean: Trinidad, Jamaica, and Haiti. Puerto Rico: University of Puerto Rico, 1965.

Sittler, J. The Ecology of Faith. Philadelphia: Muhlenberg Press, 1961. 
Sleeth, R. E. Persuasive Preaching. New York: Harper and Brothers Publishers, 1956.

Smith, M. G. The Plural Society in the British West Indies. Berkley and Los Angeles: University of California Press, 1965.

Smith, M. G.; Augier, R.; and Mettleford, Rex. The Ras-Tafari Movement in Kingston, Jamaica. Mona, Kingston: Institute of Social and Economic Research, University College of the West Indies, 1962.

Springer, J. L. "West Indian Value System and the Church's Validating Role." Troubling of the Waters. San Fernando, Trinidad: Rahaman Printery, 1973.

Statistical Yearbook of Jamaica. Jamaica: The Printing Unit, Department of Statistics, 1974.

Stone, R. "A Black Liberation Theology from Jamaica." The Christian Century 91 (Ju7y-December 1974): 750.

Sutton, A. E. Jamaica: Island of Miracles. Nashville: Southern Publishing Association, 1966.

Tertullian. Against Praxeas. The Anti-Nicene Fathers, 3:597-632.

Thayer, J. H. A Greek-English Lexicon of the New Testament. New York: American Book Company, 1886.

Thompson, J. A. Deuteronomy, An Introduction and Commentary. London: Inter-Varsity Press, 1974.

Trujil10, A. Lopez. Liberation or Revolution. Indiana: Our Sunday Visitor, 1977.

Underhill, E. B. Life of James Mursell Phillippo, Missionary in Kingston, Jamaica. London: Yates and Alexander, 1881.

Van Ruler, A. The Christian Church and the 01d Testament. Translated by C. W. Bromily. Grand Rapids: William B. Eerdmans Publishing Company, 1971.

Watty, W. "The De-Colonization of Theology." Troubling of the Waters. San Fernando, Trinidad: Rahaman Printery, 1973.

Heatherspoon, J. B. Sent Forth to Preach. New York: Harper and Brothers, $195 \overline{4}$.

Westerman, $C$. The 01d Testament and Jesus Christ. Translated by

0 . Kaste. N.p.: Augsburg House, 1970. 
White, Ellen.G. Gospel Workers. Washington, D.C.: Review and Herald Publishing Association, 1948.

- Testimonies to the Church. 9 Vols. California: Pacific Press Publishing Association, 1948.

- Positive Christian Living. Washington, D.C.: Review and Herald Publishing Association, 1952.

- Testimonies to Ministers. Washington, D.C.: Review and Herald Publishing Association, 1962.

Whitese11, F. D. The Art of Biblical Preaching. Grand Rapids: Zondervan Publishing House, 1950.

Power in Expository Preaching. N.p.: Fleming Revel Company, 1953.

Woefel, J. Bonhoeffer's Theology, Classical and Revolutionary. Nashville: Abingdon Press, 1970.

Horley, R. C. Preaching and Teaching in the Earliest Church. Philadelphia: The Westminster Press, 1952.

Wright, E. E. God tho Acts, Biblical Theology as Recital. London: SCM, $19 \overline{52}$.

Wright, G. Ernest. "Exegesis of the Book of Deuteronomy." The Interpreter's Bible. Nashville: Abingdon Cokesbury $\overline{\text { Press, }}$ $1953,2: 312$.

Wright, P. Knibb: "The Notorious" Slaves' Missionary 1803-1845. London: Sidgwick and Jackson, 1973.

Yates, K. M. Preaching from the Prophets. New York: Harper and Row Brothers Publishers, 1942. 
VITA

Name: Vassel George Kerr

Date and Place of Birth:

April 11, 1940; Hanover, Jamaica, W. I.

Undergraduate \&

Graduate Schools West Indies College, Mandeville, Jamaica, W. I. Attended:

Fuller Theological Seminary, Pasadena, California

Andrews University, Berrien Springs, Michigan

Degrees Awarded: 1968 Bachelor of Theology, Lest Indies College, Jamaica, W. I.

1978 Master of Divinity, Andrews University

1979 Doctor of Ministry, Andrews University

Work Experience: 1959-1967 Literature Evangelist, West Jamaica Conference of SDA, Jamaica, W. I.

1966 Student Leader for Literature Evangelism, West Jamaica Conference of SDA, Jamaica, W. I.

1968-1974 Pastor-Evangelist, West Jamaica Conference of SDA, Jamaica, W. I.

1975-1978 Student Leader for Literature Evangelism, Ontario Conference of SDA, Oshawa, Ontario, Canada. 